\title{
UN NOU CERCEL DESCOPERIT LA ORAŞUL DE FLOCI (COMUNA GIURGENI, JUDEŢUL IALOMITA)
}

Silviu OTA

\section{A NEW EARRING FOUND IN ORAȘUL DE FLOCI (COMM. OF GIURGENI, IALOMITA COUNTY)}

A kiln was discovered in 1999, during the archaeological excavations in Oraşul de Floci (comm. of Giurgeni, Ialomita county). In the upper part of a pit situated in front of the kiln, at $0.95 \mathrm{~m}$ depth, among other ceramic fragments, was found an earring, made of copper, ornamented with six spiral wires. The earring comes from the level of destruction, after the abandonment of the kiln, and was dated by a coin issued during the reign of Ferdinand I (1526-1564). The house situated in its south-eastem part was dated latter, according to the stratigraphy and the coins issued in 1551, during the reign of Ferdinand I. Most probably, the earring can be dated sometime between the years 1526 and 1551.

KEYWORDS: earring, workshop, bronze, coins, kiln. CUVINTE CHEIE: cercel, atelier, bronz, monede, cuptor.

Cercetările de la Oraşul de Floci (PI. 1), desfãşurate în cursul anilor 1996-1999, pe grindul numărul şase, au dus la identificarea unor complexe arheologice importante pentru clarificarea activităţilor desfăşurate în acest sit. Printre altele, enumerăm o locuinţă depozit pentru lingouri şi turte de bronz ${ }^{1}$, dar şi câteva ustensile meşteșugărești, un atelier de prelucrare a bronzului în care se falsificau şi monede din veacul al XVI-lea ${ }^{2}$, o matriţă de produs lumânări ${ }^{3}$, cuptoare diverse, un număr important de monede ${ }^{4}$, dar şi gropi menajere în care se aruncau reziduuri provenite de la aceste ateliere ${ }^{5}$ (Pl. 2). Lor li se adaugă un număr important de locuinţe rămase încă sumar publicate, de regulă în rapoarte de săpătură ${ }^{6}$.

În cursul cercetărilor efectuate în cursul anului $1999^{7}$, pe grindul nr. 6, a fost descoperit un cercel din bronz. Acesta provine dintr-o zonă cu reziduuri menajere din faţa unui cuptor fost cuptor, surprins în S. II/1999 (orientată V-E, dimensiuni: 1,5

\footnotetext{
${ }^{1}$ Chițescu et alii 1997, 45; Oţa 2006, 225-235.

2 Oţa, Pârvan, Constantinescu 2006, 94; Oța, Pârvan, Constantinescu 2004-2007, 68.

${ }^{3}$ Oţa, Pârvan 2005, 259-265.

${ }^{4}$ Oţa, Pârvan 2003, 241-247.

${ }^{5}$ Mihai, Oţa 1999, 77-78; Păunescu, Oţa 2000, 39.

6 În acest sens vezi Cronica Cercetărilor Arheologice din România, campaniile 1996-1999.

${ }^{7}$ Păunescu, Ota 2000, 38-39.
}

$\times 6,00 \mathrm{~m}$ ), la adâncimea de $0,95 \mathrm{~m}$, nu departe de atelierul de prelucrare a bronzului, unde se falsificau şi monede emise în veacul al XVI-lea ${ }^{8}$.

Complexe arheologice contemporane cu acest cuptor au fost gropile 1/1999, 3/1999, 5/1999 şi 8/1999 .

\section{STRATIGRAFIA SECTIUNII}

Cuptorul (PI. 4) a fost amenajat prin săparea unei gropi în sol steril (Pl. 3). Fundul acesteia a fost surprins la adâncimea de 1,43-1,68 $\mathrm{m}$ de la nivelul de călcare actual. În interior au fost găsite o piatră, o bucată de chirpici ars şi lemn carbonizat. În faţa sa era o groapă cu lăţimea de $0,92 \mathrm{~m}$. Pe fundul său, la adâncimea de $1,40 \mathrm{~m}$, în centru era o piatră cu dimensiunile de 0,15 $\mathrm{m} \times \mathbf{0 , 0 7} \mathrm{m}$. În jurul ei au fost bucăţi de pământ ars, la adâncimi de 1,28-1,49 m, cu diverse dimensiuni. Pe profilul nordic, se poate observa arderea pereţilor săi. Cuptorul avea o gură îngustă de $27 \mathrm{~cm}$. Pe profilul sudic şi pe planul secţiunii, s-a observat că avea o lăţime de $1,15 \mathrm{~m}$.

\footnotetext{
${ }^{8}$ Oţa, Pârvan, Constantinescu 2006, 94.

9 Pentru cronologică și stratigrafia complexelor arheologice din campania 1999, vezi Păunescu, Oţa $2000,38-39$.
} 
Lungimea cuptorului şi a gropii din faţa sa nu a fost surprinsă, deoarece nu a fost cercetată întreaga zonă. În lateralul său, în partea vestică era o treaptă. Fundul său a fost surprins la adâncimea de $1,43 \mathrm{~m}$.

Materialul arheologic recuperat din cuptor şi din groapa din faţa sa este extrem de sărac. Acesta constă în câteva fragmente ceramice.

Peste nivelul de steril arheologic, a fost realizată o amenajare de pământ marozgrunţuros, cu grosimea de $0,18-021 \mathrm{~m}$. La rândul său, aceasta a fost suprapusă de o zonă cu reziduuri care conţinea fragmente de lemn carbonizat, pietre, resturi ceramice, bucăţele de bronz, resturi osteologice provenite de la animale, bucăţele de chirpici, un cercel (găsit în partea estică a fostei gropi din faţa cuptorului, între reziduuri) şi o monedă păstrată fragmentar, datată în cursul secolului al XVI-lea, probabil emisă în timpul domniei lui Ferdinand I $(1526-1564)^{10}$. Pe profilul sudic, spre vest se poate observa că zona cu reziduuri menajere a avut două faze de utilizare. Foarte probabil, cea timpurie, era contemporană cu Locuinţa nr. 1/1999.

În lateralul reziduurilor, spre est, a fost construită locuinţa nr. 1/1999 (surprinsă în S2/1999 şi caseta 2/1999), iar spre vest atelierul de prelucrare a bronzului. Locuinţa nr. 1/1999, a avut două faze de amenajare. Prima dintre ele, consta dintr-o podea de lut cu grosimi variabile de $0,06-$ $0,10 \mathrm{~m}$. Peste ea se observă diverse depuneri din timpul utilizării, inclusiv o groapă care a fost fie practicată în podea, fie provine din momentul dezafectării primei faze de utilizare. Apoi a fost amplasată o podea de lemn, care la un moment dat a fost incendiată. În această locuinţă, într-o vatră alveolată datând din prima fază de utilizare a complexului, au fost descoperite două monede, ambele emise în anul 1551, în timpul lui Ferdinand $I^{11}$. Aceasta demonstrează că cercelul şi moneda descoperite în faţa cuptorului sunt foarte probabil din al doilea sfert al secolului al XVI-lea.

\footnotetext{
${ }^{10}$ Oţa, Pârvan 2003, 246.

" Oţa, Pârvan 2003, 246.
}

Stratigrafia secţiunii indică faptul că cercelul provine dintr-o etapă în care o parte a primelor complexe descoperite de aici au fost dezafectate.

Lângă locuinţă, exista o zonă în care se depozitau, peste şi lângă fostul cuptor, reziduuri menajere. Cercelul în discuţie provine exact din spaţiul afectat cuptorului, dar la un moment în care acesta nu mai exista.

\section{DESCRIEREA PIESEI (PL. 5)}

Veriga cercelului, deformată, este confecţionată dintr-o sârmă de bronz, circulară în secţiune (Diametrul $=18,5 \mathrm{~mm}$ $\times 14,5 \mathrm{~mm}$; diametrul sârmei $=1,1 \mathrm{~mm}$ ). Montura centrală (Diametrul $=10 \mathrm{~mm}$ ) a fost confecţionată din şase tuburi din sârmă de bronz spiralată $(\mathrm{L}=7,1 \mathrm{~mm}$, Diametrul unui tub $=3 \mathrm{~mm}$ ), puse unul lângă altul, în jurul verigii. De o parte şi de alta a sa a fost înfăşurată în jurul verigii sârmă de bronz simplă pentru fixare.

Greutatea sa este de 1,33 grame, necurăţată. Piesa este în stare proastă de conservare.

Pentru identificarea relativă a compoziţiei, cercelul de bronz a fost supus unei analize de laborator, fiind efectuate măsurători prin fluorescenţă de raze $X$, cu ajutorul unui spectrometru portabil tip InnovX Alpha Series, prevăzut cu anticatod din $\mathrm{W}$, detector SiPIN cu răcire prin efect Peltier, tensiunea aplicată $30 \mathrm{kV}$, intensitatea 40 micro $A$ şi un timp de achiziţie $30 \mathrm{~s}^{12}$.

12 Măsurătorile au fost efectuate în data de 05.03.2012, de către inginer Migdonia Georgescu (Centrul Naţional de Cercetări și Investigaţii FizicoChimice şi Biologice), căreia îi mulţumim şi pe această cale. 


\begin{tabular}{|l|c|c|c|c|c|c|}
\hline Reading & $\begin{array}{c}\text { Descrier } \\
\mathrm{e}\end{array}$ & $\mathrm{Fe}$ & $\mathrm{Cu}$ & $\mathrm{Pb}$ & $\mathrm{As}$ & $\mathrm{Sn}$ \\
\hline 2 & resort & 0.001 & 87.5 & 1.03 & 0.25 & 11.22 \\
\hline 3 & veriga & 0.001 & 98.49 & 0.9 & & 0.61 \\
\hline 4 & veriga & 0.001 & 98.6 & 0.77 & & 0.63 \\
\hline $\begin{array}{l}0.001-\text { în } \\
\text { urmă }\end{array}$ & & & & & & \\
\hline
\end{tabular}

Conform acestei analize, se poate spune că piesa a fost confecţionată din bucăţi de metal diferite. Astfel veriga a fost din cupru, și avea foarte probabil pe exterior staniu pentru a da impresia că este o piesă de argint sau argintată. Tubuleţele de sârmă care formau montura aveau o cantitate mult mai mare de staniu pe exterior $(11,22 \%)$, ceea ce indică intenţia clară de a acoperi cuprul în aliaj cu plumb din care au fost confecţionate.

Veriga piesei este una comună pentru cerceii acestei perioade, de regulă de mici dimensiuni. Montura din tubuleţe de sârmă este una care momentan nu are analogii. Folosirea tuburilor de sârmă, din argint, bronz sau aur era destul de frecventă în spaţiul actual al României, măcar din secolul al XIV-lea. Ea poate fi observată pe piese din tezaurele de la Olteni ${ }^{13}$, Tifeşt $i^{14}$, Jiana Mare ${ }^{15}$, Zăvoaia ${ }^{16}$, Bălțatji ${ }^{17}$, Brătuşeni ${ }^{18}$, Oneşti ${ }^{19}$, Musait ${ }^{20}$, Bălıata ${ }^{21}$ etc., dar numai ca element auxiliar de decor, nu principal (Vadu Anei ${ }^{22}$ ) sau singular ca în cazul cercelului în discuţie.

13 Rosetti 1972, 9-10, 12, fig. 23; 13, fig. 25; Dumitriu 2001, 130, Taf. $42 / 4$.

${ }^{14}$ Moisil 1916, 12-13 şi ilustraţia (cele două perechi de cercei).

${ }^{15}$ Dumitriu 2001, 127, Taf. 39/1-2, 4, 5, 5a.

${ }^{16}$ Dragomir 1972, 67, 69, fig. 1/1-2; Dumitriu 2001, 139 , Taf, $51 / 3-4$.

${ }^{17}$ Butnariu et alii 2007, 70, 71, fig. 1-6; 72.

${ }^{18}$ Butnariu 1994, 18-19, 129, fig. XVIII/1-5.

${ }^{19}$ Butnariu 1994, 21, 130, fig. XIX/6-7.

${ }^{20}$ Butnariu 1994, 25-26, 130, fig. XX/1, 4 -6, fig. XXI/1, 3-4, fig. XXII/1-2, 4-9.

${ }^{21}$ Butnariu 1994, 34-35, 130, fig. XXX/6, 8-10.

${ }^{22}$ Dumitriu 2006, 352, 355, Pl. 1/4.
Cronologia tezaurelor indică o utilizare a acestui motiv decorativ de la finalul veacului al XIV-lea până la începutul celui de-al XVII-lea. Un alt fragment de piesă din argint, decorată cu tuburi de sârmă, provine din una din necropolele cercetate la Oraşul de Floci ${ }^{23}$.

În acest stadiu al cercetării piesa constituie un unicat şi nu are analogii. Având în vedere materialul din care a fost confecţionată, cred că este produsul unui atelier local, foarte probabil chiar din această aşezare.

\footnotetext{
23 Mulţumim doamnei dr. Anca Păunescu pentru informaţie. Piesa se află în depozitul de metale al MNIR cu nr. inv. 297137 și a fost descoperit în anul 1996, în necropola nr. 5, S. 90, M. 840. Veriga cercelului conţinea următoarele elemente chimice: $\mathrm{Ni}$ $=0,001, \mathrm{Cu}=0,001, \mathrm{Au}=0,28, \mathrm{~Pb}=0,09, \mathrm{Bi}=$ 0,001, $\mathrm{Ag}=99,63$, iar omamentul: $\mathrm{Cu}=0,001, \mathrm{Au}=$ $0,001, \mathrm{~Pb}=0,001, \mathrm{Bi}=0,001, \mathrm{Ag}=100$.
} 


\section{Butnariu 1994}

Butnariu 2007

Chiţescu et alii 1997

Dragomir 1972

Dumitriu 2001

Dumitriu 2006

Mihai, Ota 1999

Moisil 1916

Oţa 2006

Oţa, Pârvan 2003

Oţa, Pârvan 2005

Oța, Pârvan, Constantinescu 2006

Oţa, Pârvan, Constantinescu 2004-2007

Păunescu, Oţa 2000

Rosetti 1972
V.M. Butnariu (coord.), Tezaure din muzeele orașului Chișinău. Secolele XVI-XVIII, Chişinău, 1994.

V.M. Butnariu (coord.), Monnaies et parures du Musée Départamental "Stefan cel Mare" de Vaslui, Iaşi, 2007.

L. Chiţescu, A. Păunescu, D. Mihai, S. Teodor, S. Oța, 78. Piua Petri, Jud. Ialomifa, CCA. Campania 1996, 1997, 44 45.

I.T. Dragomir, Tezaurul de la Zăvoaia (jud. Brăila), BMI, 2, 1972, 67-73.

L. Dumitriu, Der Mittelalterliche Schmuck des Unteren Donaugebietes im 11.-15. Jahrhundert, București, 2001.

L. Dumitriu, Objets de parure de la nécropole de Vadu Anei, CAMNI, XIII, 341-362.

D. Mihai, S. Oł̦a, 95. Oraşul de Floci - com. Giurgeni, jud. Ialomiţa, CCA. Campania 1998, 1999, 77-78.

C. Moisil, Monete şi podoabe de la sfârșitul secolului al XV-lea (Tezaurul de la Tifești, jud. Putna), BSNR, XIII, 1916, 27, ianuarie-martie, 3-16.

$S$. Oța, Un dépôt de lingots et tourteaux de bronze découverte dans Orașul de Floci (comm. de Giurgeni, dép. de Ialomiţa), Istros, 13, 2006, 225-235.

S. Oţa, K. Pârvan, Monede medievale descoperite la Piua Petrii (Oraşul de Floci), com. Giurgeni, judeţul Ialomita, în campanile arheologice din anii 1996, 1998-1999 (I), CAMNI, 12, 2003, 241-247.

S. Oța, K. Pârvan, O matriţă pentru producerea de lumânări descoperită la Oraşul de Floci (com. Giurgeni, jud. Ialomita), Istros, XII, 2005, 259-265.

S. Oţa, K. Pârvan, B. Constantinescu, Remarks regardingthe analyses of some bronze objects discovered in Oraşul de Floci (village of Giurgeni, district of Ialomiţa), Numizmatika, Bratislava-Smolník, 2006, 21, 87-99.

S. Oța, K. Pârvan, B. Constantinescu, Câteva observaţii privind analiza câtorva piese de bronz descoperite la Oraşul de Floci (com. Giurgeni, judeţul Ialomiţa), grindul nr. 6, ActaMN. Historica, 41-44/II, 2004-2007, 65-81.

A. Păunescu, S. Oţa, 57. Giurgeni, com. Giurgeni, jud. Ialomiţa [Oaşul de Floci], CCA. Campania 1999, 2000, 38-39.

D. V. Rosetti, Tezaurul de podoabe medievale de la Olteni (Teleorman) şi elementele lor bizantine, $B M I, 41,4,1972,3-14$.

LISTA ILUSTRATIEI

Pl. 1. Harta cu amplasarea Oraşului de Floci.

Pl. 2. Grindul nr. 6 cu poziţia piesei.

Pl. 3. Profilul sudic şi nordic al S. II/1999.

PI. 4. Planul cuptorului şi cercelul descoperit în S. II/1999.

PI. 5. Cercelul descoperit în $S$. II/1999, fotografii şi radiografie.

\section{LIST OF PLATES}

Pl. 1. The map with the geographical position of Orașul de Floci.

Pl. 2. The top of the bank ridge no. 6, with the position of the earring.

PI. 3. The northern and southem profiles of S. II/1999.

PI. 4. The plan of the kiln and the earring found in S. II/1999.

PI. 5. The earring found in S. II/1999, photos and radiographies.

Silviu OŢA

Muzeul Național de Istorie a României

Calea Victoriei 12, 030026, Bucureşti

silviuota@yahoo.com 


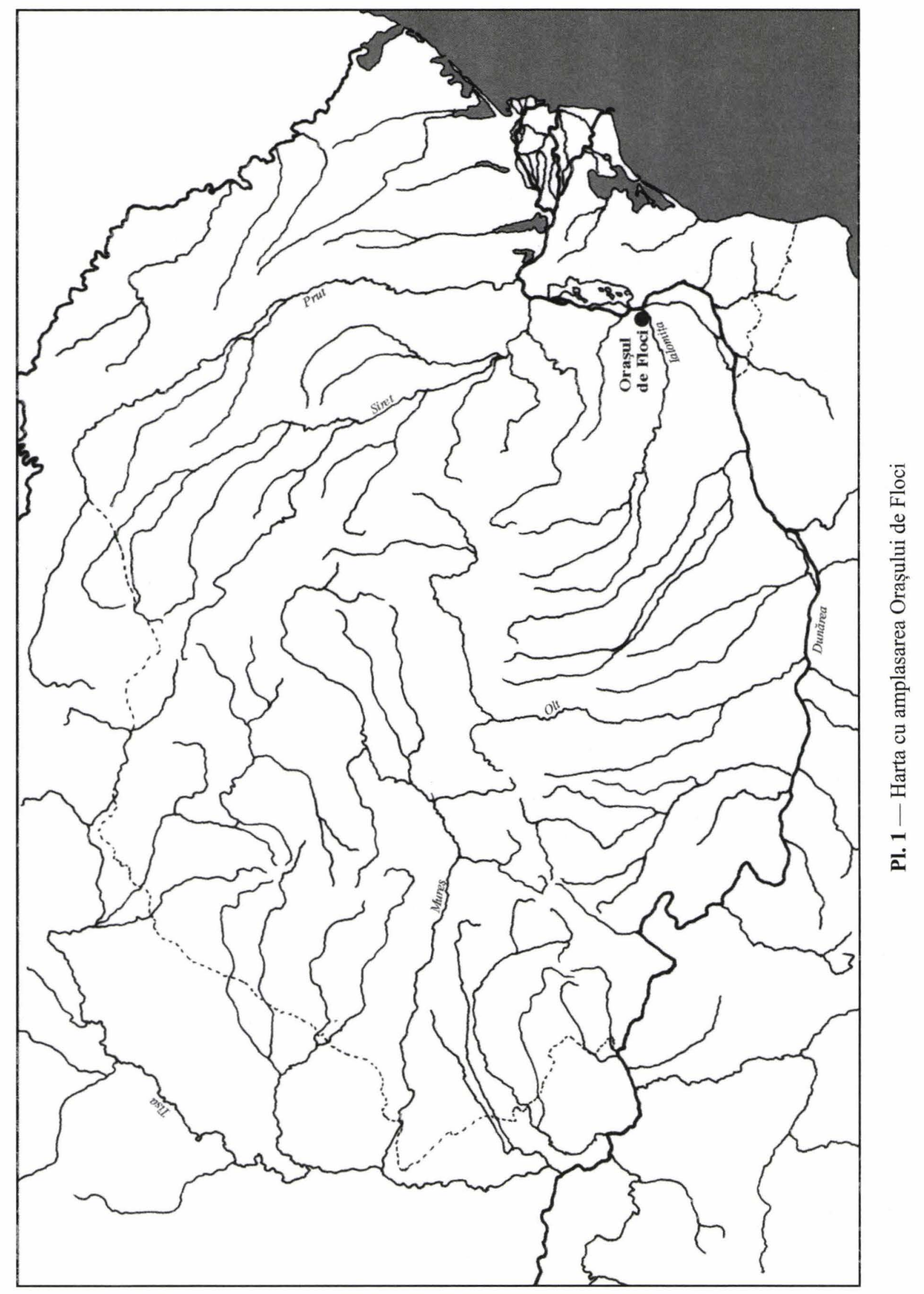


ORASULDE FLOCI Punct Piua Petri, comuna Giurgeni, județul Ialomița

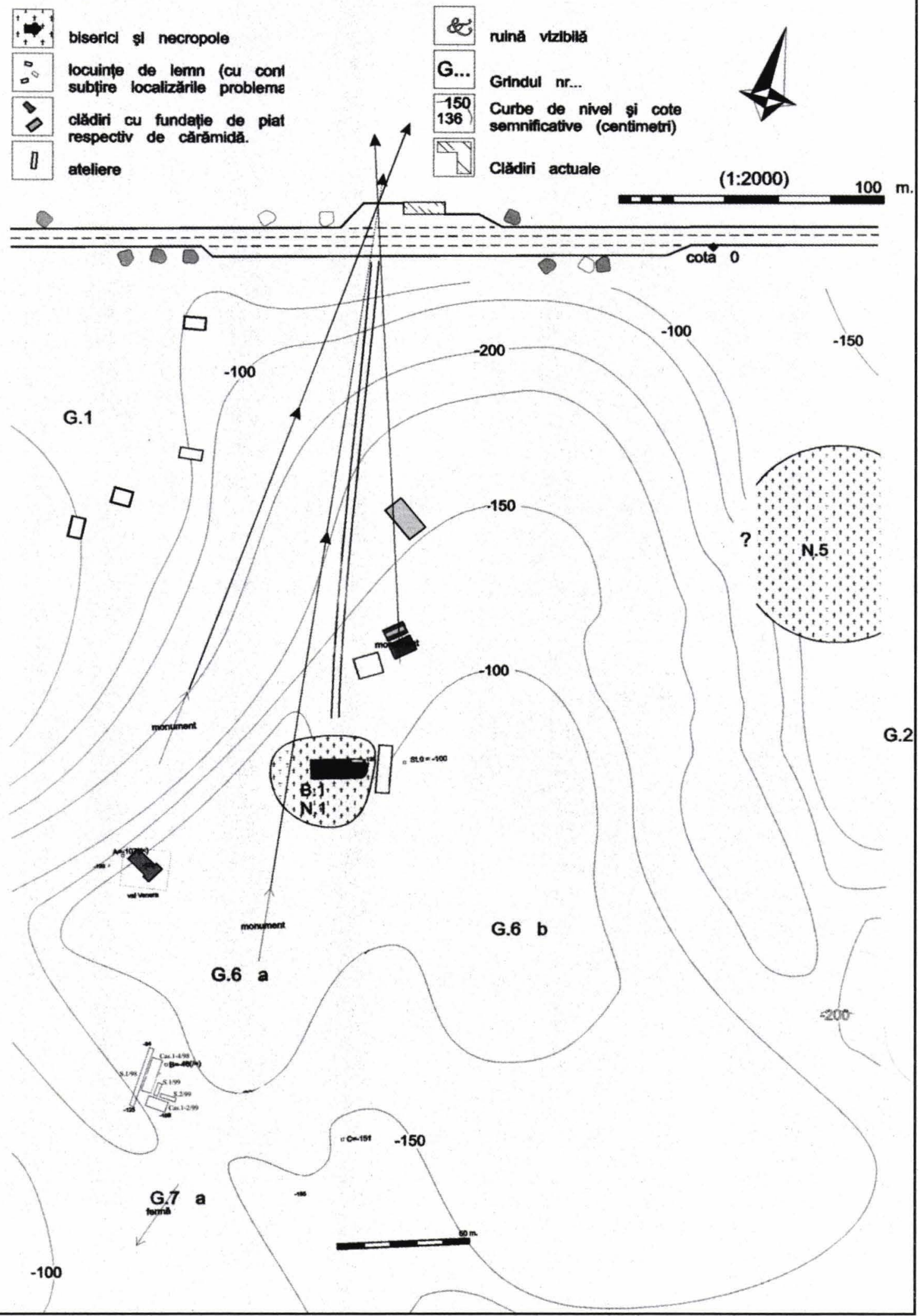

PI. 2 - Gridul nr. 6 cu poziția piesei 


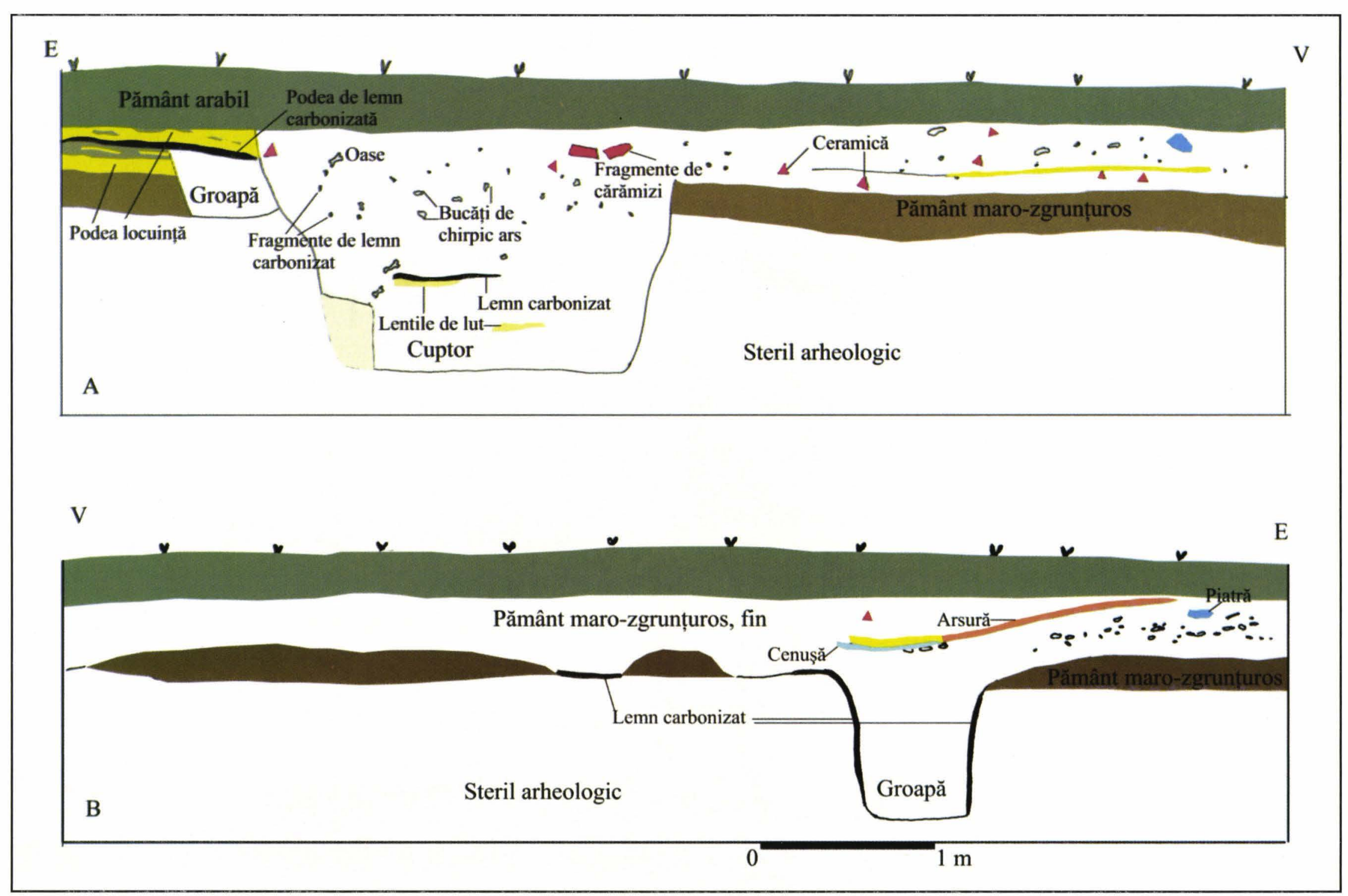

Pl. 3 — Profilul sudic și nordic al S II/1999 


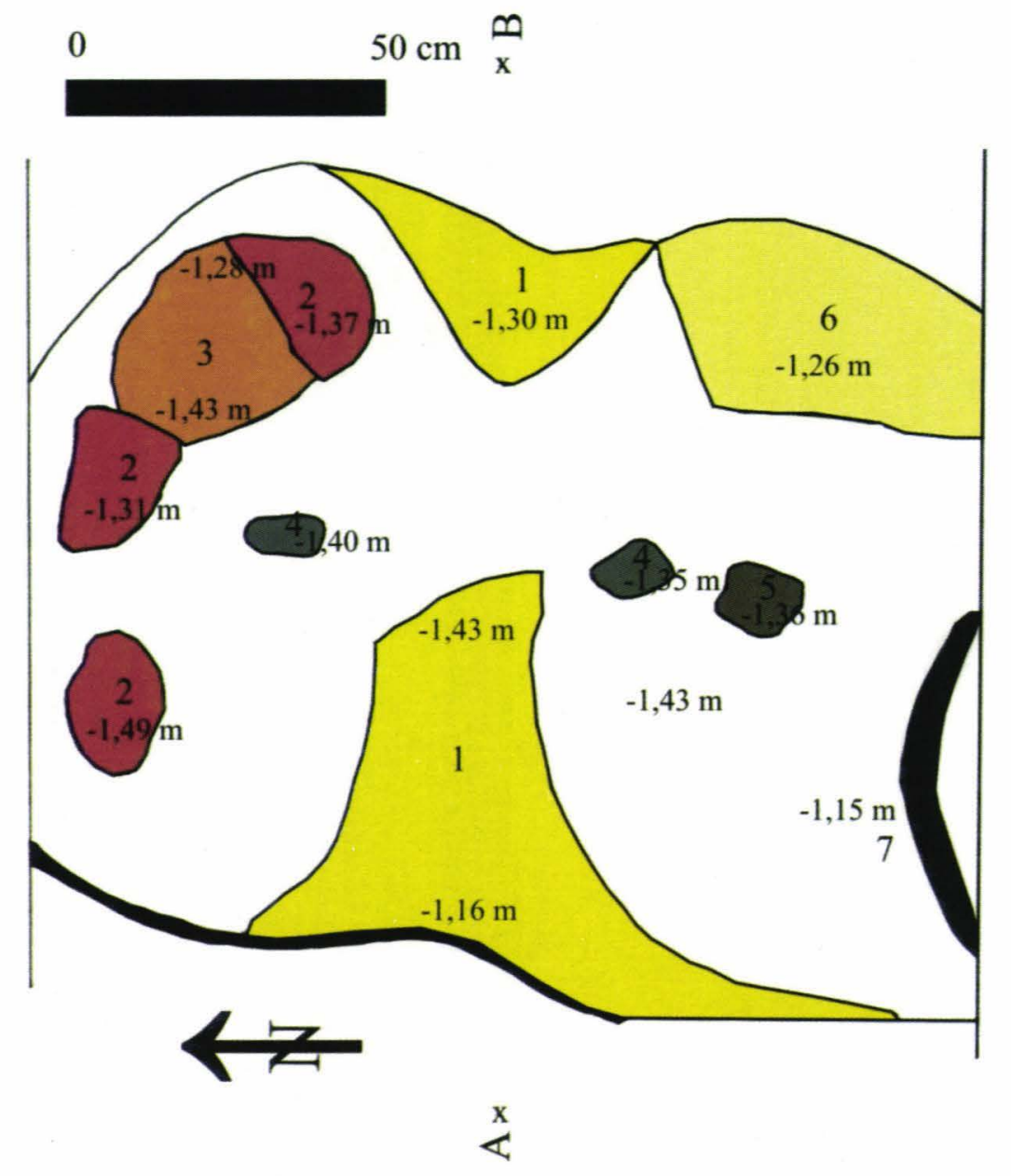

Legenda

1 - Lut

2 - Lut ars

3 - Lut ars sfărâmat

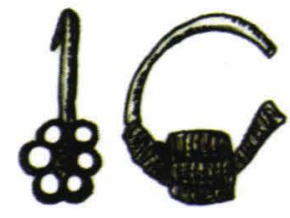

4 - Pietre

5 - Chirpic de culoare maro

6 - Amenajare cu lut în cuptor

7 - Lemn carbonizat

PI. 4 - Planul cuptorului și cercelul descoperit în S II/1999 


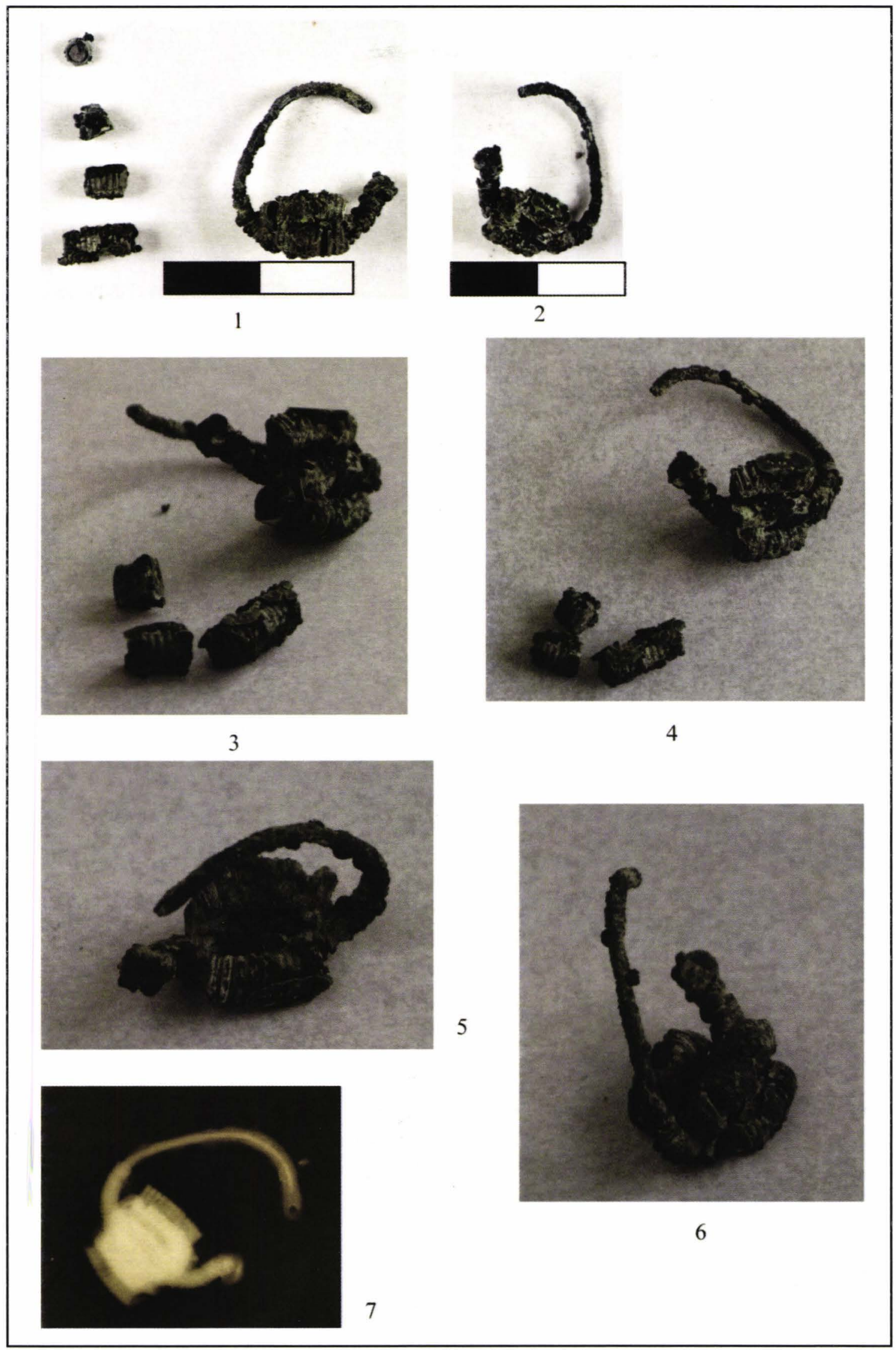

Pl. 5 - Cercelul descoperit în S II/1999, fotografii și radiografie 



\section{CÂTEVA BUNURI ARHEOLOGICE DE VALOARE EXCEPTIONALĂ PENTRU CUNOAŞTEREA CIVILIZAŢIEI GETO-DACICE RECUPERATE RECENT. EXPERTIZE ARHEOLOGICE}

George TROHANI

\section{QUELQUES OBJETS ARCHEOLOGIQUES D'UNE VALEUR EXCEPTIONNELLE CONCERNANT LA CONNAISSANCE} DE LA CIVILISATION DES GETO-DACES RECEMMENT RECUPERES. EXPERTISES ARCHEOLOGIQUES

D'a peu pré une décade la mass media parle des bracelets en or, des écus en fer et de divers monnaies en argent et or, toutes des pièces gèto-daces découvertes dans les alentours de Sarmizegetusa, l'ancienne capitale de la Dacie. Comme suite des conditions de leur découvertes et des contextes dans les quels elles ont été faites connu au public large, elles n'ont pas bénéficié d'une publication strictement scientifique. Pour cela, dans les suivantes pages, ont présente les expertises faites par divers scientifiques, membres des commissions d'expertise sollicitées par le Ministère de la Culture, pendant les années 20062011.

MOTS CLEFS : bracelets, écus, monnaies, or, argent, fer, gèto-daces. CUVINTE CHEIE: brăłări, scuturi, monede, aur, argint, fier, geto-daci.

De peste şase ani se tot vorbeşte, în mass media, despre brăţările dacice plurispiralice din aur. Din cauza condiţiilor în care au fost descoperite, a modului în care au ajuns a fi cunoscute de către publicul larg, dar şi de către specialişti, a litigiilor în care se mai află, nu s-a putut face o publicare ştiinţifică a lor. Dar în diverse publicaţii de popularizare, în reviste pseudoştiinţifice, în cataloage de expoziţii temporare au apărut scurte prezentări'. Dar au fost şi unii cercetătorii, mai vrednici, ce au publicat contribuţii demne de luat în seamă ${ }^{2}$.

În cele ce urmează ne propunem să prezentăm expertizele efectuate de către diferite comisii de expertiză, la solicitarea Ministerului Culturii (cu diferitele sale titulaturi), în vederea achiziţionării și recuperării lor.

\footnotetext{
I Pliante sau cataloage de expoziţie au apărut cu ocazia itinerării unora dintre brăţări la muzeele din Suceava, Sibiu, Ploiești, Alba Iulia etc.

${ }^{2}$ Barbara Deppert în Patrimonium I, 2008, 201-240 (text integral în română), 241-245 (rezumat englez) şi 246-288 (text german integral); D. Spânu, Research Issues regarding the Grădiștea de Munte Spiral Gold Bracelets Hoards. An Essay, in Revue Roumaine d'Histoire XLVIII, 2009, 1-2, 3-16; D. Spânu, Zur Analyse der Goldspiralen von Grädiştea de Munte, Rumänien, în Das Altertum 55, 2010, 4, 271-314; B. Constantinescu, Er. Oberländer-Târnoveanu şi colab. în Antiquity, vol. 84, 2010, nr. 326, 1028-1042.
}

Din Rapoartele de expertiză am selectat doar referirile stricte la partea istorică şi arheologică, cele de natură juridică şi financiar contabilă fiind evitate.

Prezentarea ce 0 facem sperăm să contribuie la o limpezire a ,misterelor" generate de aceste descoperiri ${ }^{3}$.

Demn de remarcat este însă efortul autorităţilor române de stat — procuratură, poliţie şi Ministerul Culturii, în colaborare cu autorităţi similare din străinătate- privind recuperarea lor prin achiziţii şi confiscări.

\section{I.}

Prin Ordinul nr. 2399 din 27.09.2006 al ministrului Culturii şi Cultelor, în ziua de 6 noiembrie 2006, la Frankfurt pe Main, în prezenţa d-nei expert internaţional $d r$. Barbara Deppert-Lippitz, Comisiei de experţi formată din:

1) prof. univ. dr. Mircea Babeş (Universitatea din Bucureşti şi Institutul de Arheologie Bucureşti),

2) dr. Lucia Marinescu (Muzeul Naţional de Istorie a României, din București),

3) dr. George Trohani (Muzeul Naţional de Istorie a României, din București),

\footnotetext{
3 "Mistere" generate în special de unele articole tendenţioase apărute cu predilecţie în cotidianul Adevărul
} 
i-a fost prezentat un lot format din patru brăţări spiralice din aur. Cele patru piese au fost examinate macroscopic, măsurate (diametrul şi înălţimea spiralei, grosimea tijei, lăţimea şi grosimea plăcilor terminale, greutatea) şi descrise.

\section{Brătara nr. 1 -plurispiralică $(6,5$} spirale din tijă cu secţiune circulară), din aur. Cele două extremităţi sunt aplatizate, în formă de bandă decorată, la fiecare extremitate afânu-se câte 7 palmete conţinând incizii în formă de brăduţ, iar la mijloc un şir de puncte. Brăţara prezintă în continuarea palmetelor câte o placă dreptunghiulară, terminată cu o protomă zoomorfă. Suprafaţa plăcilor dreptunghiulare este decorată cu şiruri de mici linii incizate în formă de brăduţ. Pe corpul tijei, înaintea palmetelor, au fost gravate cercuri care o înconjoară. Plăcile terminale sunt situate şi vizibile de aceeaşi parte a piesei spiralice.

$\mathrm{Nu}$ se constată degradări (deformări, lovituri, lipsuri), stadiul de conservare fïind foarte bun. Dimensiuni: D ext. $=12,4 \mathrm{~cm} ; \mathrm{H}$ $\max .=8,2 \mathrm{~cm} ; \mathrm{H}$ min. $=5,2 \mathrm{~cm}$; grosimea tijei $=4,5-5 \mathrm{~mm}$; lăţimea plăcilor terminale $=$ $1,8 \mathrm{~cm}$; grosimea plăcilor terminale $=3,4$ $\mathrm{mm}$; Lungimea barei $=2,50 \mathrm{~m}$. Greutate $=$ 981,20 grame.

Brătara nr. 2-plurispiralică spirale), din aur. Cele două extremităţi sunt aplatizate, în formă de bandă decorată, la fiecare extremitate aflându-se câte 7 palmete conţinând incizii în formă de brăduţ, iar la mijloc un şir de puncte. Brăţara prezintă în continuarea palmetelor câte $o$ placă dreptunghiulară, terminată cu o protomă zoomorfă. Suprafaţa plăcilor dreptunghiulare este decorată cu şiruri transversale constituite din incizii arcuite. Pe corpul tijei, înaintea palmetelor, sunt cercuri incizate care o înconjoară. Plăcile terminale se suprapun ca poziţie şi sunt vizibile de aceeaşi parte a piesei spiralice.

$\mathrm{Nu}$ se constată degradări, starea de conservare fiind foarte bună. Dimensiuni: D ext. $=11,4-11,7 \mathrm{~cm} ; \mathrm{H} \max .=10,2 \mathrm{~cm} ; \mathrm{H}$ min. $=7,6 \mathrm{~cm}$; Lungimea barei $=2,71 \mathrm{~m}$; Greutate $=1076,72$ grame.
Brătara nr. 3-plurispiralică, $\quad(7,8$ spirale), din aur. Cele două extremităţi sunt aplatizate, în formă de bandă decorată, la fiecare extremitate aflându-se câte 7 palmete conţinând incizii în formă de brăduţ, iar la mijloc un şir de puncte. Brăţara prezintă în continuarea palmetelor câte 0 placă dreptunghiulară, terminată cu o protomă zoomorfă. Suprafaţa plăcilor dreptunghiulare este decorată cu linii în formă de brăduţ, incizate. Plăcile terminale sunt vizibile pe aceeaşi parte a spiralei. Animalele de la extremităţi au gura marcată printr-o incizie şi ochii situati pe margini. Capetele animalelor sunt decorate cu mici cercuri. Pe corpul tijei, înaintea palmetelor, sunt cercuri incizate care o înconjoară.

Uşoară deformare a spiralei. Dimensiuni: $\mathrm{D}$ ext. $=10,4-10,5 \mathrm{~cm}$; $\mathrm{H}$ max. $=$ $7,5 \mathrm{~cm}$; D tijă $=4,5-5 \mathrm{~mm}$; Lăţimea plăcilor terminale $=1,9 \mathrm{~cm}$; Lungimea barei $=2,85$ m. Greutate $=1115,31$ grame.

Brătara nr. 4-plurispiralică $(6,5$ spirale), din aur. Cu cele două extremităţi sunt aplatizate, în formă de bandă decorată, la fiecare extremitate aflându-se câte 7 palmete conţinând incizii în formă de brăduţ, iar la mijloc un şir de puncte. Brățara prezintă în continuarea palmetelor câte $o$ placă dreptunghiulară, terminată cu o protomă zoomorfă. Suprafaţa plăcilor dreptunghiulare este decorată cu şiruri transversale conţinând incizii arcuite. Pe corpul tijei, în faţa palmetelor, sunt cercuri incizate ce o înconjoară. Plăcile terminale sunt vizibile pe aceeaşi parte.

Deformare uşoară a spiralei. Dimensiuni: $\mathrm{D}$ ext. $=10,4-10,6 \mathrm{~cm} ; \mathrm{H} \max =$ $11 \mathrm{~cm}$; $\mathrm{H} \mathrm{min} \mathrm{=} \mathrm{7,5} \mathrm{cm;} \mathrm{grosimea} \mathrm{tijei}=4-6$ $\mathrm{mm}$; lăţimea plăcilor terminale $=1,9 \mathrm{~cm}$; Lungimea barei $=2,06 \mathrm{~m}$. Greutate $=927,98$ grame.

\section{CONSTATĂRI}

De la început se impune constatarea maximei asemănări a pieselor examinate, din aur, cu brătările de formă spiralică, din argint, cunoscute din descoperirile mai vechi de tezaure dacice de podoabe de argint, din epoca geto-dacă clasică (sec. II a. Chr.-I p. Chr.). În 
fapt, pentru această epocă se constată o cantitate foarte redusă de obiecte din aur, în raport cu numeroasele obiectele din argint, apărute în cea mai mare parte sub formă de tezaure (cca. 65). Conform unor statistici recente numărul total de obiecte din argint (piese de port şi podoabă, vase) descoperite în spaţiul locuit de către geto-daci, care în linii mari coincide cu teritoriul de astăzi al României, este de 822. Din aur nu sunt decât 27 piese, provenind din 14 locuri de descoperire. De aici rezultă importanţa cu totul particulară a obiectelor din aur, în special a acelora descoperite în ultimii ani în cuprinsul unor adevărate tezaure. Ca urmare a eforturilor investigative ale organelor judiciare, în aceşti ani s-a semnalat descoperirea, prin detectări şi săpături ilegale, a două astfel de tezaure, cuprinzând un număr de $15(10+5)$ brăţări plurispiralice din aur, de mari dimensiuni. Piesele examinate la Frankfurt au făcut parte dintr-unul dintre aceste două tezaure, localizate de anchetatori în situl arheologic „Căprăreaţa”, din apropierea cetătii regale dacice de pe Dealul Grădiştii (Grădiştea Muncelului).

Brăţările de aur examinate prezintă toate caracterele tipologice (formă, ornamentică) ale celor cca. 30 de brăţări spiralice de argint, cunoscute anterior, provenind în marea lor majoritate (28 exemplare) de pe teritoriul României. În chip special se remarcă asemănarea cu exemplarele de argint de la Cărpeniş, Coada Malului, Senereuş şi Orăştie. Asemănarea evidentă dovedeşte că piesele de aur sunt contemporane cu cele de argint şi, ca urmare, se datează în a doua jumătate a sec. I a. Chr. Totodată, analogia ne arată că meşterii argintari daci erau capabili să lucreze şi în aur, atunci când comanditarul dorea acest lucru şi putea să livreze materia primă, aurul.

Raritatea extremă a podoabelor dacice din aur, de felul brăţărilor examinate, dimensiunile lor excepţionale (greutăţi de 900-1100 g!), perfecţiunea execuţiei, locul şi circumstanţele descoperirii se pot foarte probabil explica prin folosirea lor în cadrul unor ceremonii fastuoase, în care se îmbinau factorul politic cu cel religios. Având în vedere faptul că ele au fost descoperite în proximitatea capitalei regale de la
Sarmizegetusa Regia, ele reflectă rangul excepţional avut de către cei ce le-au comandat şi le-au purtat, în cadrul ierarhiei social-politice şi religioase a regatului dac în sec. I a. Chr. (în mare, epoca lui Burebista). $\mathrm{Nu}$ este, de aceea, exagerat a considera aceste piese drept podoabe şi însemne de rang regal.

\section{CONCLUZII}

1. Piesele prezentate sunt brăţări spiralice din aur aparţinând unei categorii de podoabe tipic dacice, cunoscute însă anterior exclusiv prin exemplare de argint, databile în a doua jumătate a sec. I a. Chr. Aceeaşi este şi datarea pieselor de aur. Având în vederea raritatea şi valoarea mare a metalului, dimensiunile mari şi excelenta execuţie, piesele de aur pot fi considerate podoabe şi însemne de rang regal dacic.

2. Piesele examinate nu prezintă indicii care să sugereze că ar putea fi vorba de piese contrafăcute. Piesele au fost evident curăţate (spălate) de descoperitori şi nu prezintă patină sau urme ale şederii lor în pământ. Uşoara deformare a două dintre piese, probabil ca urmare a presiunii pământului/ pietrelor, poate fi interpretată ca un indiciu de autenticitate. Sub rezerva unor analize fizice şi chimice, care ar face doar să sporească valoarea muzeală şi ştiinţifică a brăţărilor cercetate, comisia a ajuns la concluzia că este vorba despre piese originale, aparţinând orfevrăriei geto-dace. Având în vedere asemănările de execuţie şi de stare de păstrare este de admis că cele patru piese au fost descoperite împreună, ca părţi ale aceluiaşi tezaur (depozit), îngropat cândva în a doua jumătate a sec. I a. Chr.

3. Având în vedere răspândirea celor 30 de brăţări spiralice de argint dacice cunoscute (28 în România, una în Serbia şi una în Bulgaria), se poate spune cu maximă probabilitate că cele patru brăţări de aur expertizate provin din spaţiul Daciei preromane, respectiv al României de astãzi. Concluziile anchetei judiciare, după care este chiar vorba de zona Dealul GrădiștiiSarmizegetusa Regia, sunt susţinute de faptul că în această zonă, începând cu anul 1803, sau descoperit mai multe tezaure monetare de aur, totalizând mai multe mii de emisiuni 
Koson şi Pseudo-Lysimach. Monedele ar putea fi sursa de aur din care au fost confecţionate astfel de brățări.

4. Fiind autentice şi provenind de pe teritoriul României, cele patru brătări examinate trebuie încadrate în inventarul Patrimoniului Cultural Naţional, clasa Tezaur.

\section{II.}

Prin Ordinul nr. 2399 din 27.09.2006 de ministrul Culturii şi Cultelor, în comisia de expertizare formată din:

1) prof. univ. dr. Mircea Babeş (Universitatea din Bucureşti şi Institutul de Arheologie București),

2) dr. Lucia Marinescu (Muzeul Naţional de Istorie a României, București),

3) dr. George Trohani (Muzeul Naţional de Istorie a României, Bucureşti),

i-a fost prezentată o brăţară dacică din aur pentru care în data de 6 februarie $2007 \mathrm{~s}$-a efectuat un Raport de expertiză.

Brătara nr. 5-plurispiralică (6,5 spirale), din aur. Cele două extremităţi sunt aplatizate, de formă dreptunghiulară. Corpul este decorat pe fiecare extremitate cu câte 7 palmete conţinând incizii în formă de linie în zigzag, iar în mijloc un şir de puncte, totul încadrându-se în romburi, iar pe muchii sunt linii incizate. Brăţara conţine la extremităţi câte o placă dreptunghiulară terminată cu un cap de animal stilizat, în relief, cu botul teşit drept ca un rât de porc. Suprafaţa plăcilor dreptunghiulare este decorată cu linii oblice incizate şi incizii punctiforme dispuse liniar. Plăcile terminale sunt vizibile pe aceeaşi parte. Pe corpul tijei, în faţa palmetelor, sunt cercuri incizate ce o înconjoară.

Deformare uşoară a spiralei. Pe două palmete s-au constat insignifiante degradări ale decorului, prin tocire, iar pe partea dorsală a palmetelor mici puncte incizate, stadiul de conservare fiind foarte bun. Dimensiuni: $\mathrm{D}=$ $11,5 \mathrm{~cm} ; \mathrm{H} \max =16 \mathrm{~cm}$; grosimea tijei $=3,5$ $\mathrm{mm}$; lăţimea plăcii $=1,9 \mathrm{~cm}$; lungimea desfăşurată a piesei este de $2,38 \mathrm{~m}$; Greutate $=764,95$ grame; iar titlul de 22.3 carate.

\section{CONSTATĂRI}

Brăţara nr. 5 se deosebeşte de celelalte patru prin cel mai înalt titlu al aurului, dar şi printr-un stil mai elaborat al decorului.

Brăţara de aur examinată prezintă toate caracterele tipologice (formă, ornamentică) ale celor cca. 30 de brăţări spiralice de argint, cunoscute anterior, provenind în marea lor majoritate (28 exemplare) de pe teritoriul României, precum şi cu cele patru din aur expertizate anterior. În chip special se remarcă asemănarea cu exemplarele de argint de la Cărpeniş, Coada Malului, Orăştie şi Senereuş. Asemănarea evidentă dovedeşte că piesele de aur sunt contemporane cu cele de argint şi, ca urmare, se datează în perioada secolului I a. Chr. Totodată, analogia ne arată că orfevrarii daci erau capabili să lucreze şi în aur, atunci când comanditarul dorea acest lucru şi putea să livreze materia primă, aurul.

\section{CONCLUZII}

\section{Piesa prezentată este o brăţară} plurispiralică din aur aparţinând unei categorii de podoabe tipic dacice, cunoscută însă anterior exclusiv prin exemplare de argint, databile în secolul I a. Chr. Aceeaşi este şi datarea prezentei piese din aur. Având în vedere raritatea şi valoarea mare a metalului, dimensiunile mari şi excelenta execuţie, piesa din aur poate fi considerată podoabă şi însemn de rang regal dacic.

2. Piesa este din aur nativ obţinut în antichitate prin ,cemerea" nisipului aurifer şi culegere de pepite din zăcământ şi/sau din pâraiele/râurile care curgeau în acea vreme prin zonă, în porţiunea lor cea mai apropiată de zăcăminte.

Acest aur, care se află în proporţie de circa $92,08 \%$, este caracterizat printr-un conţinut de argint de circa 7,66\%, precum şi de fier de circa $0,27 \%$.

Valorile concentraţiilor de $\mathrm{Au}$ şi $\mathrm{Ag}$, precum şi prezenţa unor elemente minoritare în aliajul din care a fost prelucrată brăţara, precum şi ne-omogenitatea relativă a structurii piesei, indică faptul că este vorba despre aur nativ (aur în stare naturală), nerafinat, care să-i mărească concentraţia în 
aur fin, în detrimentul argintului, sau altor elemente prezente în aliajul primar.

3. În privinţa tehnicii de prelucrare meşteșugarii geto-daci au utilizat, atât metoda topirii, cât şi a baterii/forjării la cald. Decorul palmetelor a fost obţinut prin stanţare.

Neomogenitatea accentuată a aliajului din care a fost realizată brăţara supusă investigaţiilor indică faptul că avem de a face cu o tehnică metalurgică de tip vechi, puţin sofisticată şi că cei care au comandat confecţionarea acesteia nu erau interesaţi sau nu stăpâneau tehnologia necesară rafinării aurului.

Pentru finisare, meșterii au folosit nicovale, poansoane, dăltiţe şi stanţe. În diferite aşezări geto-dace din sec. II a. Chr. I p. Chr. se cunosc ateliere sau obiecte de bijutier la Costești, Grădiştea de Munte, Pecica, Ardeu, Surcea etc.

4. Piesa examinată nu prezintă indicii care să sugereze că ar putea fi vorba despre o contrafacere. Piesa a fost evident curăţată (spălată), dar se observă vagi urme ale şederii ei în pământ prin existenţa unor depuneri în anumite pliuri şi zone unghiulare. $O$ uşoară deformare a corpului piesei, probabil ca urmare a presiunii pământului/pietrelor, poate fi interpretată ca un indiciu de autenticitate. Comisia a ajuns la concluzia că este vorba de o piesă originală, aparţinând orfevrăriei getodace. Având în vedere asemănările de execuţie şi de stare de păstrare este de admis că şi această piesă a fost descoperită împreună cu celelalte patru brăţări expertizate anterior, ca parte a aceluiaşi tezaur (depozit), îngropat cândva în a doua jumătate a sec. I a. Chr.

De asemenea, s-a putut observa la analiza fizică că suprafaţa brăţării este acoperită cu o patină translucidă, de culoare uniformă, uşor maronie, care atenuează strălucirea naturală a aurului prelucrat mecanic. Aspectul acestei suprafeţe patinate contrastează puternic cu cea a ariilor unde au avut loc frecări recente, datorită manipulării neatente a brătării după descoperire. Aspectul acestei patine rezultă din depuneri extrem de fine de carbonaţi şi sulfaţi de calciu, magneziu prezenţi în sol.

5. După părerea membrilor comisiei, füind autentică și provenind de pe teritoriul României, şi această a cincea brăţară examinată este încadrată în inventarul
Patrimoniului Cultural Naţional, clasa Tezaur.

III.

Pentru aceste prime cinci brăţări, în urma Rezoluţiilor din 10 ianuarie 2007 şi 24 ianuarie 2007 ale Ministerului Culturii şi Cultelor, dintre cei cinci experţi care urmau a examina brăţările din aur dacice doar doi s-au deplasat în data de 1 februarie 2007 la Muzeul Naţional de Istorie a României din Bucureşti unde au primit spre expertiză piesele menţionate.

Este vorba de:

1) dr. Eugen Iaroslavschi, CSP I la Muzeul Naţional de Istorie a Transilvaniei,

2) dr. Aurel Rustoiu, CSP II la Institutul de Arheologie şi Istoria Artei din Cluj-Napoca.

Iată pe scurt opiniile dânșilor legate de aceste piese:

Brăţara nr. 1. Este de tip plurispiralic, numărând 6,5 spire. A fost confecţionată din aur nativ de mare fineţe. Chiar în faţa noastră s-au efectuat măsurători prin metode moderne, nedistructive, şi am aflat că procentul de aur este (în porţiunea testată) de $87,69 \%$, argint $11,16 \%$, cupru $0,93 \%$, plumb $0,22 \%$. Pe lângă aceste elemente există şi urmele altora $(\mathrm{Mn}, \mathrm{Fe}, \mathrm{Co}, \mathrm{Ni}, \mathrm{Be}, \mathrm{Zn}, \mathrm{Hg}$, As, Se, Sn, Sb, ş.a.), care însoţesc elementul major şi care vor putea servi la identificarea, măcar cu aproximaţie, a zonei de unde a fost extras sau cules aurul.

Este de menţionat, între elementele aflate în urme, prezenţa mercurului $(\mathrm{Hg})$, ceea ce ar putea fi pus în legătură cu metoda de separare a paietelor din aluviunile aurifere.

Din spusele specialiştilor care efectuau măsurătorile am mai reţinut că de-a lungul tijei spiralice puritatea aurului nu este aceeaşi, ea variind destul de mult, menţinându-se însă la un nivel ridicat tot timpul. Considerăm foarte importantă această remarcă, deoarece ea confirmă faptul că brățările acum în discuţie au fost realizate prin forjarea mai multor bucăţi de aur ce puteau fi mici lingouri rezultate din topirea nisipului de aur sau fragmente de filon.

Am măsurat cu metrul de croitorie lungimea spiralei şi am constatat că ea avea cca. 2,5 m. Capetele tijei au fost mai întâi aplatizate, iar apoi acea porţiune a fost 
împărţită în trei câmpuri distincte. Cel de la extremitate imită într-o formă schematizată un cap de şarpe, apoi urmează o porţiune mai lată, relativ orizontală, decorată cu mai multe linii incizate în formă de brăduţ şi, în sfârşit, o porţiune decorată cu şapte palmete care sunt flancate de brâuri supraînălţate, decorate cu linii fine incizate. Porţiunea aplatizată şi tija rotundă în secţiune sunt unite de incizii rotunjite care marchează conturul tijei în porţiunea vizibilă, din faţă şi lateral.

Numărul de palmete cu care este decorată brătara este de câte şapte la fiecare din cele două capete. Felul în care sunt ele marcate nu este însă identic. Astfel, la unul din capete avem primele trei palmete realizate cu aceeaşi stanţă, lungă de $1,9 \mathrm{~cm}$. Urmează apoi alte două realizate cu o stantă având $1,75 \mathrm{~cm}$ şi în sfârşit, alte două având $1,6 \mathrm{~cm}$. În schimb capătul opus al brăţării are palmetele $1-5$ identice şi realizate cu ştanţa cu care au fost marcate primele trei de la capătul descris anterior, iar cea de a şasea şi cea de a şaptea sunt asemănătoare cu cele deja descrise. La realizarea decorului au fost utilizate 3 ştanţe la un capăt şi doar două dintre ele la celălalt. De remarcat că după ştanţare porţiunea nu a mai fost cizelată.

Brăţara nr. 2. Foarte asemănătoare celei de mai sus, la prima vedere, totuşi la o analiză atentă prezintă destule deosebiri.

În primul rând, puritatea aurului (în porţiunea care a fost verificată în faţa noastră) este mai mică, argintul, cuprul, fierul şi cositorul fỉind elementele însoţitoare în cantitate mai mare.

Protoma zoomorfã de la capăt reprezintă tot un cap de şarpe, dar diferit redat. Cizelarea părţilor laterale ale acestuia este foarte bună, în vreme ce conturul lateral nu este compus dintr-un număr egal de incizii şi acestea nu sunt dispuse simetric. Suprafaţa dreptunghiulară intermediară este decorată cu şiruri transversale constând din linii incizate fin, arcuite. Ambele capete au fost decorate folosindu-se câte două tipuri de ştanţe, primele cinci fiind identice, iar ultimele două deosebite, dar toate de aceeaşi lungime. Lungimea totală a tijei este de $2,71 \mathrm{~m}$.

Brăţara nr. 3. Este confecţionată dintr-un aur nativ cu o puritate (în porţiunea examinată în faţa noastră) de $82,37 \%$, ceea ce înseamnă aproximativ 19,76 carate. Tija avea o lungime de $2,85 \mathrm{~m}$ şi are capetele aplatizate ca în cazul precedentelor, dar numărul de spire e mai mare cu una.

Capetele sunt asemănătoare, protomele reprezentând acelaşi animal-şarpe-redat schematizat. Gura şarpelui este marcată în părţile laterale printr-o incizie, iar ochii sunt realizaţi cu un poanson separat de tip priducea.

Suprafaţa plăcuţelor dreptunghiulare intermediare este decorată cu linii incizate în formă de brăduţ. Porţiunea următoare este decorată cu palmete aplicate în mod identic la ambele capete. Constatăm că primele şase palmete au fost imprimate, la ambele capete, cu aceeaşi stantă, iar cea de a şaptea cu una diferită. Între palmete se află câte un cerc incizat, de asemenea, prin ştanţare, se pare cu aceeaşi stantă cu care au fost marcaţi şi ochii.

Brăţara nr. 4. A fost lucrată de asemenea dintr-un aur de mare puritate (în porţiunea examinată în faţa noastră) care avea $91,07 \% \mathrm{Au}$, adică aproximativ 21,86 carate. Lungimea totală a tijei este de $2,06 \mathrm{~m}$ şi formează 6 spire. La vârfuri are aceleaşi capete de şarpe redate schematizat, iar porţiunea intermediară, dreptunghiulară, este decorată cu şiruri transversale de incizii arcuite. Cea de a treia porţiune, decorată cu palmete a fost marcată de şapte ori cu aceeaşi stanţă la unul din capete. Cel de al doilea capăt are ultima palmetă ceva mai mică, dar credem că aceasta se datorează nu schimbării ştanţei, ci diminuării câmpului printr-o ciocănire ulterioară.

Brățara nr. 5. Deşi în linii mari se aseamănă cu primele patru este totuşi destul de deosebită. În primul rând aurul are o culoare mai puţin roşiatică (din conţinutul său lipsind probabil cuprul sau fiind mult mai puţin), apoi tija chiar dacă are $2,38 \mathrm{~m}$ lungime, fiind mai subţire, cântărește mult mai puţin decât celelalte. Aurul este foarte pur în porţiunea examinată ajungând la $92,08 \%$, adică peste 22 de carate.

Partea de la vârf a brăţării este tot o protomă zoomorfă, chiar dacă nu putem spune cu certitudine că este şarpe. Botul animalului seamănă mai degrabă cu un rât de porc decât cu gura unui şarpe. Suprafaţa plăcilor dreptunghiulare este decorată cu linii oblice incizate, cea mai mare parte a lor 
constituind niște romburi, restul spaţiului fiind umplut cu alte liniuţe şi puncte dispuse liniar. Porţiunea decorată cu palmete este identică, la ambele capete fiind utilizată aceeaşi stanţă de câte şapte ori. Ştanţa folosită este mult mai complicată decât la celelalte brățări, între nervurile incizate fiind plasate o mulţime de puncte mici, iar pe axul palmetei, mici perle marchează locul în care se întâlnesc nervurile. Marginile palmetelor, supraînălţate în mod similar celor de la restul brăţărilor, sunt decorate cu mult mai multe incizii imprimate cu dăltiţe diferite, de $o$ fineţe deosebită.

Constatăm că toate cele cinci brătări descrise mai sus au multe asemănări cu cele din argint descoperite anterior şi păstrate în câteva muzee din ţară şi străinătate. Între cele de argint există şi unele cărora le lipsește partea decorată, precum şi altele care au capul de şarpe redat diferit, fără acea porţiune aplatizată și decorată. Şi în cazul brătărilor de argint există exemple în care protoma redă şarpele cu mare stângăcie, ceea ce (la fel ca în cazul brăţării nr. 5) a permis unele ezitări în a le defini ca atare. Uneori s-a spus că reprezintă un cap de câine, alteori de berbec. Credem însă că şi acolo unde există asemenea situaţii avem de a face tot cu capete de şarpe. Această opinie este întărită şi de forma multispiralică a brăţărilor, precum şi de câmpurile decorate de la capete. În porţiunea dreptunghiulară intermediară între protomă şi palmete, fie că sunt incizate linii ondulate, fie aranjate în zig-zag, sugerează mişcarea alunecoasă, şerpuirea.

Caracteristic tuturor brăţărilor este repetarea de şapte ori a decorului în formă de palmetă. Acest lucru nu poate fi întâmplător, asupra cifrei şapte, atât în antichitate, cât şi în Evul Mediu, existând numeroase credinţe şi superstiţii. Nu este cazul, credem, să insistăm asupra semnificaţiilor cifrei şapte acum, subiectul fiind tratat pe larg într-o bibliografie largă.

Chiar dacă mai existā câteva piese de aur de epocă dacică, este o realitate faptul că numărul descoperirilor este foarte mic. Descoperirea celor 5 brăţări despre care discutăm acum, precum şi mult sperata recuperare a celorlalte despre care se vorbeşte, este un lucru cu adevărat extraordinar. Piese confectionate din aur de mare fineţe şi cu o asemenea greutate fac plauzibilă opinia exprimată de regretatul $\mathrm{H}$. Daicoviciu că doar regelui îi era permisă folosirea podoabelor de aur masiv, nobilimea trebuind să se mulţumească cu strălucirea mai puţin intensă a argintului.

Dacă se va adeveri că ele au fost dezgropate din imediata apropiere a Sarmizegetusei Regia va fi o dovadă în plus că ele au aparţinut unei persoane de cel mai înalt rang politico-religios şi pot fi chiar socotite însemne de rang regal.

Putem spune în concluzie:

1. Piesele reprezintă brăţări spiralice din aur asemănătoare celor cunoscute până acum doar prin exemplare din argint. Datorită rarităţii, dar şi valorii deosebite, piesele pot fi socotite însemne de rang regal.

2. Metalul conţinut este aur nativ de o mare fineţe. Adaosul de argint şi cupru, dar şi de alte elemente în urme, nu constituie un fapt neobişnuit. Aceste elemente se găsesc împreună cu aurul şi studierea lor în amănunt de către geologi, fizicieni, chimişti pot aduce detaliile dorite în legătură cu locul de provenienţă al aurului. Faptul că de-a lungul pieselor compoziţia nu este omogenă dar rămâne constant una de mare fineţe este dovada ca la confecţionat s-au folosit mai multe bucăţi de aur obţinut prin topirea nisipului şi a unor capete de filon. Primele patru brăţări au o compoziţie asemănătoare, iar cea de a cincea are elemente de aliere diferite, remarcabile şi în culoarea mai deschisă, mai palidă. Nu ştim câte zone din această brăţară au fost analizate sub aspectul purităţii aşa că nu știm dacă compoziţia ei este omogenă sau suferă variaţii. Dacă nu există acest gen de analiză, sugerăm ca ea să se facă, bineînţeles de preferat fiind o metodă nedistructivă.

3. Aurul este unul nativ aflat, după opinia noastră, la prima prelucrare. Din studiile regretatului profesor Eugen Stoicovici se ştie că aurul coloidal roşu este specific Transilvaniei. Dacă analizele vor stabili această caracteristică, vom avea dovada utilizării unei resurse autohtone. Noi înclinăm spre această atribuire. Prezenţa mercurului sar explica prin utilizarea sa în operaţiunile de separare. E de reamintit în acest context 
existenţa unor resurse de mercur la Izvorul Ampoiului (fostă Valea Dosului) şi utilizarea lor în antichitate.

4. În ceea ce privește tehnica obţinerii aurului din nisipul aluvionar, cu siguranță dacii cunoşteau metoda topirii şi tumării aurului în lingouri de mici dimensiuni. Temperatura de topire a aurului, de $1063^{\circ} \mathrm{C}$, era destul de uşor de obţinut, iar mai apoi lingourile puteau fi cu uşurinţă deformate, mai ales dacă erau încălzite în prealabil.

5. Primele patru brăţări sunt cu siguranţă piese autentice şi credem că au fost lucrate în acelaşi atelier de către un meşter orfevrier dac. Asupra celei de a cincea brăţări am dori înainte să ne exprimăm opiniile să avem câteva date suplimentare. În primul rând, o analiză a conţinutului său pe cât mai multe segmente de-a lungul tijei spre a vedea dacă a fost confecţionată dintr-o singură bucată de aur masiv sau din mai multe. Apoi am dori o analiză de detaliu a urmelor metalelor însoţitoare şi câteva radiografii, atât asupra capetelor, cât şi asupra tijei, radiografii în care se vor urmări eventuale fisuri, goluri în interior etc. Decorul aplicat pe această piesă, chiar dacă este asemănător cu al celorlalte patru, este mult mai bogat, meşterul străduindu-se să umple cu punctulețe şi liniuţe întreaga suprafaţă. Aceasta face notă discordantă cu sobrietatea stilului constatat la celelalte patru brăţări de aur sau pe cele de argint. Ni se pare că această brătară este produsul altui atelier dar deocamdată, până la obţinerea rezultatelor analizelor solicitate şi eventual până la recuperarea şi a celorlalte brăţări, nu putem spune mai mult.

6. Din punct de vedere arheologic, piesele provin, aşa cum declară şi descoperitorii, din zona capitalei Daciei-Sarmizegetusa Regia.

7. Piesele discutate, provenind dintr-un sit arheologic de mare importanţă, confecţionate din metal preţios, decorate ca adevărate opere de artă antică, fiecare în parte constituind un unicat, aparţin Patrimoniului Cultural Naţional şi trebuie incluse in categoria TEZAUR.

\section{IV.}

Brățara nr. 6 fiind recuperată de către autorităţile române nu a necesitat o expertiză specială. De aceea facem doar o scurtă prezentare a ei.

Brătara nr. 6 plurispiralică (4,5 spirale), din metal galben. Brăţara prezintă la extremităţi mai întâi un cap de animal, stilizat, ce redă un şarpe cu botul lung şi decorat cu linii arcuite. Urmează o placă dreptunghiulară a cărei suprafałă este decorată cu şiruri transversale constituite din incizii arcuite, dispuse în 4 grupe şi jumătate de metope. Pe corp, urmează un decor compus din 7 palmete conţinând incizii în formă de brăduţ şi la mijloc un şir de puncte. Pe corpul tijei, înaintea palmetelor, sunt două grupe a două cercuri incizate care o înconjoară. Plăcile terminale sunt opuse ca mod de suprapunere.

$\mathrm{Nu}$ se constată degradări, starea de conservare fiind foarte bună. Dimensiuni: D $\max .=12,5 \mathrm{~cm} ; \mathrm{H} \max .=13,3 \mathrm{~cm}$; grosime $6 \mathrm{~mm} ; \mathrm{L}=178 \mathrm{~cm}$. Greutate $=1062,55$ grame.

La solicitarea doamnei expert internaţional dr. Barbara Deppert-Lippitz s-a alcătuit următorul Tabel cu dimensiunile primelor şase brăţări

Dimensions des bracelets daces en or :

\begin{tabular}{|c|l|l|l|l|l|l|l|l|l|}
\hline bracelet & $\begin{array}{l}\text { longueur } \\
\text { décor }\end{array}$ & $\begin{array}{l}\text { longueur } \\
\text { bouche } \\
\text { ictc } \\
\text { palmette }\end{array}$ & $\begin{array}{l}\text { longueur } \\
\text { tête }\end{array}$ & $\begin{array}{l}\text { hauteur } \\
\text { lête }\end{array}$ & $\begin{array}{l}\text { épaisse } \\
\text { plume }\end{array}$ & $\begin{array}{l}\text { épaisse } \\
\text { entre } \\
\text { plume }\end{array}$ & $\begin{array}{l}\text { diam. } \\
\text { spirale } \\
\text { décor }\end{array}$ & $\begin{array}{l}\text { diam. } \\
\text { spirale a } \\
\text { l'endroii } \\
\text { de la lête }\end{array}$ & $\begin{array}{l}\text { diam. } \\
\text { spirale } \\
\text { milieu }\end{array}$ \\
\hline $1 \mathrm{a}$ & $22 \mathrm{~cm}$ & $6 \mathrm{~cm}$ & $3 \mathrm{~cm}$ & $5,5 \mathrm{~mm}$ & $6,5 \mathrm{~mm}$ & $4,5 \mathrm{~mm}$ & $6,5 \mathrm{~mm}$ & $6 \mathrm{~mm}$ & $5 \mathrm{~mm}$ \\
\hline $1 \mathrm{~b}$ & $22 \mathrm{~cm}$ & $6 \mathrm{~cm}$ & $3 \mathrm{~cm}$ & $6 \mathrm{~mm}$ & $5 \mathrm{~mm}$ & $3,8 \mathrm{~cm}$ & $5,5 \mathrm{~mm}$ & $5,5 \mathrm{~mm}$ & \\
\hline $2 \mathrm{a}$ & $22 \mathrm{~cm}$ & $6 \mathrm{~cm}$ & $2 \mathrm{~cm}$ & $5 \mathrm{~mm}$ & $3 \mathrm{~mm}$ & $2 \mathrm{~mm}$ & $5,5 \mathrm{~mm}$ & $5 \mathrm{~mm}$ & $5,2 \mathrm{~mm}$ \\
\hline $2 \mathrm{~b}$ & $21,5 \mathrm{~cm}$ & $5,5 \mathrm{~cm}$ & $2 \mathrm{~cm}$ & $6 \mathrm{~mm}$ & $3 \mathrm{~mm}$ & $2 \mathrm{~mm}$ & $5,5 \mathrm{~mm}$ & $5 \mathrm{~mm}$ & \\
\hline $3 \mathrm{a}$ & $25,5 \mathrm{~cm}$ & $6,7 \mathrm{~cm}$ & $3 \mathrm{~cm}$ & $5,2 \mathrm{~mm}$ & $2,8 \mathrm{~mm}$ & $1,9 \mathrm{~mm}$ & $6 \mathrm{~mm}$ & $5 \mathrm{~mm}$ & $4,9 \mathrm{~mm}$ \\
\hline $3 \mathrm{~b}$ & $24,5 \mathrm{~cm}$ & $6,2 \mathrm{~cm}$ & $2,5 \mathrm{~cm}$ & $6,5 \mathrm{~mm}$ & $3 \mathrm{~mm}$ & $2 \mathrm{~mm}$ & $6 \mathrm{~mm}$ & $6 \mathrm{~mm}$ & \\
\hline $4 \mathrm{a}$ & $22 \mathrm{~cm}$ & $6,1 \mathrm{~cm}$ & $2,7 \mathrm{~cm}$ & $6 \mathrm{~mm}$ & $3 \mathrm{~mm}$ & $2 \mathrm{~mm}$ & $6,5 \mathrm{~mm}$ & $5 \mathrm{~mm}$ & $4,8 \mathrm{~mm}$ \\
\hline
\end{tabular}




\begin{tabular}{|c|l|l|l|l|l|l|l|l|l|}
\hline $4 \mathrm{~b}$ & $22,4 \mathrm{~cm}$ & $6,1 \mathrm{~cm}$ & $2,3 \mathrm{~cm}$ & $6,5 \mathrm{~mm}$ & $4 \mathrm{~mm}$ & $3 \mathrm{~mm}$ & $6,2 \mathrm{~mm}$ & $5 \mathrm{~mm}$ & \\
\hline $5 \mathrm{a}$ & $23 \mathrm{~cm}$ & $7,5 \mathrm{~cm}$ & $2,5 \mathrm{~cm}$ & $5 \mathrm{~mm}$ & $3 \mathrm{~mm}$ & $2 \mathrm{~mm}$ & $6,5 \mathrm{~mm}$ & $5 \mathrm{~mm}$ & \multirow{3}{*}{$3,5 \mathrm{~mm}$} \\
\hline $5 \mathrm{~b}$ & $23,5 \mathrm{~cm}$ & $7,3 \mathrm{~cm}$ & $2,5 \mathrm{~cm}$ & $5,5 \mathrm{~mm}$ & $3 \mathrm{~mm}$ & $2 \mathrm{~mm}$ & $6,2 \mathrm{~mm}$ & $5 \mathrm{~mm}$ & \\
\hline $6 \mathrm{a}$ & $21 \mathrm{~cm}$ & $5,8 \mathrm{~cm}$ & $2,4 \mathrm{~cm}$ & $6,7 \mathrm{~mm}$ & $4 \mathrm{~mm}$ & $2,5 \mathrm{~mm}$ & $7 \mathrm{~mm}$ & $6 \mathrm{~mm}$ & $6 \mathrm{~mm}$ \\
\hline $6 \mathrm{~b}$ & $21 \mathrm{~cm}$ & $5,5 \mathrm{~cm}$ & $2,2 \mathrm{~cm}$ & $7 \mathrm{~mm}$ & $4,5 \mathrm{~mm}$ & $2,5 \mathrm{~mm}$ & $7 \mathrm{~mm}$ & $6 \mathrm{~mm}$ & \\
\hline
\end{tabular}

V.

Prin Ordinul Ministrului Culturii şi Cultelor nr. 1209 din 11.06.2007 o Comisie de expertizare a trei brăţări din aur aflate la Frankfurt pe Main, formată din:

1) dr. George Trohani, CSP I la Muzeul Naţional de Istorie a României,

2) dr. Eugen Iaroslavschi, CSP I la Muzeul Naţional de Istorie a Transilvaniei,

s-a deplasat în zilele de 14-16 iunie 2007 la Frankfurt am Main, Germania, unde în prezenţa d-nei expert internaţional $d r$. Barbara Deppert-Lippitz, a efectuat o expertiză ale cărei rezultate, redactate în ziua de 17 iunie 2007, sunt redate mai jos.

Brătara nr. 7. Este de tip plurispiralic, numărând 6 spire şi trei sferturi, ea cântărind 1.196,03 grame. A fost confecţionată din aur nativ foarte asemănător la aspect cu primele patru. Nu am avut posibilitatea să efectuăm o analiză de finețe a conţinutului brăţării, dar după aspect şi greutate credem că este unul foarte asemănător cu acela al pieselor deja investigate.

Am măsurat lungimea spiralei şi am constatat că ea avea $2,50 \mathrm{~m}$. Grosimea tijei din care a fost confecţionată brăţara este de $0,55 \mathrm{~cm}$., cu mici variaţiuni de-a lungul lungimii. Capetele tijei au fost mai întâi aplatizate, iar apoi acea porţiune a fost împărţită în trei câmpuri distincte. Cel de la extremitate imită într-o formă schematizată un cap de şarpe, apoi urmează o porţiune mai lată, relativ orizontală, decorată cu mai multe linii incizate în formă de brăduţ. Părţile laterale ale acestei porţiuni sunt uşor supraînălţate şi, la rândul lor, decorate cu scurte linii incizate dispuse în formă de spinare de peşte. În sfârşit, cea mai lungă porţiune este decorată cu şapte palmete, imprimate prin ştanţare, care sunt la rândul lor flancate de brâuri supraînălţate, decorate cu linii fine incizate. Porţiunea aplatizată şi tija, rotundă în secţiune, sunt unite de incizii rotunjite care marchează conturul tijei în porţiunea vizibilă, din faţă şi lateral. Se observă trei linii duble incizate între care se află două câmpuri mai înalte cu o mică creastă centrală. Partea dinspre tija netedă este decorată cu o linie în zig-zag, incizată. Locul de întâlnire a liniei frânte este marcat prin mici puncte obţinute cu ajutorul unui instrument ascuţit.

Partea decorată, cu toate cele trei porţiuni ale sale, are o lungime totală de $24 \mathrm{~cm}$.

Numărul de palmete cu care este decorată brăţara este de câte şapte la fiecare din cele două capete. Felul în care sunt ele marcate nu este însă identic. Astfel, la unul dintre capete avem primele şase palmete realizate cu aceeaşi stanţă, lungă de $1,8 \mathrm{~cm}$. Urmează apoi a şaptea palmetă realizată cu o stanţă având 1,6 cm. De remarcat că după ştanţare porţiunea nu a mai fost cizelată.

$\mathrm{Nu}$ suntem siguri că stanţa cu care au fost aplicate este aceeași cu care a fost aplicat decorul pe brăţările deja cunoscute. Vor trebui făcute aceste comparaţii având în faţă toate brăţările. La prima impresie am spune că unele stanţe au fost folosite pe mai multe brăţări.

$\mathrm{Ca}$ o particularitate a acestei brăţări remarcăm la unul dintre capete, în locul unde prima palmetă se uneşte cu coama, aplicarea prin ciocănire cu un poanson minuscul, de dimensiunile unui ac, a două marcaje sub forma unor arcade în genul pavilionului unei urechi umane. Decorul este însă atât de discret făcut încât nu poate fi văzut decât cu ajutorul lupei.

Tot la această brătară se remarcă pe spatele porţiunii aplatizate existenţa unor incizii, făcute cu un vârf subţire, extrem de fine, invizibile cu ochiul liber. Una din incizii seamănă cu o inimă, dar poate, în acelaşi timp, să fie o încercare de a trasa o literă, de pildă litera $\langle\mathrm{O}\rangle$, moment în care mâna celui ce o trasa a tremurat. Cealaltă incizie poate fi fie litera $\langle\mathrm{Z}\rangle$, fie litera $\langle\mathrm{N}\rangle$, depinde de poziţia din care citim. Aceste incizii ce pot fi văzute doar cu ajutorul lupei, sunt cu certitudine aplicate relativ recent, probabil de către unul din cei ce a avut în posesie piesa respectivă. 
Revenind la porţiunea decorată cu palmete, remarcăm că acestea au fost obţinute prin aplicarea unei lovituri puternice unor stanţe ce aveau imprimat decorul în negativ. După părerea expertului german, doamna dr. Barbara Deppert-Lippitz, operaţiunea s-a făcut la rece, aurul nefiind în prealabil încălzit. Domnia sa a experimentat pe o tijă de plumb, aplicând cu ajutorul unei stanţe asemănătoare, de câteva ori un decor similar. Deşi suntem convinşi că va scrie chiar Domnia Sa despre rezultatele acestui experiment foarte interesant, suntem şi noi de aceeaşi părere că bordurile supraînălţate au apărut în același timp cu stanțarea decorului, metalul moale ridicându-se datorită loviturii putemice din zona centrală. Când s-a aplicat la unul din capete cea de a şaptea palmetă, lovitura nu a fost suficient de puternică, lucru ce 1-a nemulţumit pe meșterul care a decis aplicarea unei lovituri suplimentare. Acest lucru este vizibil, nervurile palmetei fiind dublate şi uşor încălecate în acel loc.

În ceea ce ne priveşte pe noi, nu suntem convinşi că operaţiunea $\mathrm{s}-\mathrm{a}$ făcut la rece, consistenţa şi gradul de rigiditate ale aurului, chiar la acea puritate fiind deosebite faţă de ale plumbului şi ca urmare, nu suntem siguri că nu era necesară o încălzire preliminară a metalului.

Între palmete, în centrul câmpului, este aplicat $\mathrm{cu}$ ajutorul unui poanson un decor mic, rotund, cu centrul ridicat. De remarcat că acelaşi poanson a fost folosit şi pentru marcarea mijlocului ochiului şarpelui de la capătul barei. Meşterul care a decorat brăţara deţinea probabil un instrumentar destul de redus, din care însă nu lipseau nicovala, ciocanul, cleștele, filiera, dăltiţe, poansoane, domuri, punctatoare toate de dimensiuni mici. Nu am remarcat folosirea unor instrumente de lustruire, de finisare amănunţită, de genul pilelor sau cutelor.

Creștetul capului şarpelui are o uşoară creastă mediană, de o parte şi cealaltă a căruia sunt incizate câte patru linii arcuite ce marchează curbura feţei animalului. Gura şarpelui este decorată cu linii mici incizate, iar în lateral cu câte o incizie scurtă.

Brătara nr. 8. Foarte asemănătoare celei de mai sus, la prima vedere, totuşi la o analiză atentă prezintă destule deosebiri. Brăţara are un număr de 5 spire şi jumătate, cântărind $1.136,06$ grame.

Lungimea totală a tijei este de $2,50 \mathrm{~m}$, fiind groasă de $6 \mathrm{~mm}$, cu mici variaţiuni generate de modalitatea de obţinere, prin ciocănire la rece. Lungimea decorului este de $20,3 \mathrm{~cm}$ la fiecare dintre capete.

Capul şarpelui este realizat prin decorare cu două linii incizate, de o parte şi cealaltă a unei linii centrale despicată spre coamă, realizată prin incizare.

Porţiunea dreptunghiulară aplatizată coama- are aplicat de 9 ori un decor de liniuţe fine în brăduţ, perpendiculare pe direcţia tijei. Părţile laterale ale coamei, supraînălţate, la rândul lor sunt decorate cu liniuţe fine în formă de spinare de peşte. Partea dreaptă a coamei are suplimentar aplicate un şir de incizii punctiforme. Este de subliniat că doar această brățară are marginea coamei decorată.

Palmetele au la locul de întâlnire a nervurilor mici punctişoare în relief, iar alte două puncte, tot în relief, se găsesc în partea lată a palmetei. Ceea ce deosebeşte această brăţară de toate celelalte este numărul palmetelor. Pe câtă vreme celelalte piese au câte şapte palmete, la fiecare dintre capete, brăţara numărul $8 \mathrm{nu}$ are decât şase. Dintre aceste şase palmete primele cinci au fost aplicate cu aceeaşi stanță, iar ultima cu o alta.

Porţiunea dintre palmete şi tija netedã este decorată cu un grupaj de două linii incizate ce se repetă de trei ori. Unul dintre capete are suplimentar, zona dintre linii, îmbogăţită cu liniuţe foarte fine.

Brătara nr. 9. Tija avea o lungime de 2,12 $\mathrm{m}$, iar grosimea este de 4,5-5 mm. Numărul de spire este de cinci şi trei sferturi. Cântărește 682,30 grame. Lungimea totală a porţiunii decorate este de $21 \mathrm{~cm}$.

Capul de şarpe are gura alungită, părţile laterale marcate cu linii curbe incizate, iar mijlocul cu un şir de puncte. Ochii sunt marcaţi, lateral, cu un poanson rotund.

Coama, dreptunghiulară, are pe centru un şir de incizii punctiforme, de o parte şi alta cărora sunt imprimate 10 grupe de liniute scurte incizate în formă de brăduţ. Parled stângă, supraînălţată, are un decor în forma 
spinării de peşte, iar cea dreaptă are între şirurile de liniuţe un mic spaţiu nedecorat.

Palmetele, la ambele capete, au fost aplicate de câte şapte ori folosindu-se aceeaşi stanţă, foarte asemănătoare, dar nu identică, cu cea utilizată la decorarea ultimei palmete de pe brăţara numărul 8 .

Porţiunea dintre palmete şi tija netedă este decorată cu două grupe de câte trei linii incizate.

Constatăm că toate cele trei brăţări descrise mai sus au multe asemănări cu cele anterior descoperite şi aflate deja în România. $\mathrm{Au}$ aceeaşi caracteristică fiind confecţionate din aur masiv, ce urmează a fi titrat în laboratoare de specialitate. Chiar dacă nu suntem în posesia unor date precise putem afirma că aspectul exterior este acelaşi cu cel al brăţărilor deja analizate sub acest aspect. Şi aceste brăţări au porţiunile terminale în formă de capete de şarpe, iar continuarea porţiunii decorate cu diverse incizii sugerează mișcarea şerpuită, alunecarea reptilei. Însăși forma plurispiralică a brăţărilor vine să confirme ideea aceasta.

Ca o noutate în cadrul brăţărilor dacice din aur este apariţia celei descrise la numărul 8 care are doar de şase ori aplicat decorul în formă de palmetã. Credem că este prematur să facem speculaţii pe această temă şi sperăm că vom avea în curând posibilitatea să analizăm şi alte asemenea artefacte, abia apoi îndrăznind să facem anumite încheieri. În orice caz este de reamintit că situaţia numărului inegal de palmete aplicate pe brăţări se constată şi în cazul celor făcute din argint.

O altă caracteristică a brăţărilor expertizate este faptul că nu poartă urmele unei întrebuinţări. Decorul nu este afectat de eroziune, iar porţiunile fie ele stanţate, fie doar ciocănite dovedesc că meşterul nu a fost preocupat de cizelare şi lustruire în nici un caz.

Decorul a fost aplicat doar pe porţiunea exterioară, vizibilă, a pieselor în vreme ce spre interior meşterul a ignorat complet posibilitatea înlăturării urmelor baterii.

Ca o opinie de moment socotim că piesele provin dintr-un atelier comun, eventual fiind opera aceluiaşi meşter care a fost, desigur, ajutat de unele calfe. Perioada în care au fost bătute piesele nu a fost una prea îndelungată în timp, ba din contra, am zice, că ele au fost lucrate într-un interval scurt de timp.

Cele trei piese descrise acum fac parte din acelaşi lot cu cele expertizate anterior. Sunt dacice şi provin din zona capitalei Daciei, Sarmizegetusa Regia.

Fie că au aparţinut unui rege dac, fie că au jucat un rol major în anumite ceremoniale cu caracter sacru, ce se desfăşurau în sanctuarele dacice, brăţările au o importanţă deosebită şi suntem convinşi că ele vor deveni adevărate repere pentru specialiștii care vor putea reanaliza în totalitate stadiul cunoştinţelor noastre despre fascinanta civilizaţie a daco-geţilor. Ele vor constitui un adevărat punct de cotitură pentru istoriografia lumii antice din această parte a Europei.

Greutatea lor deosebită, materialul din care sunt confecţionate, felul în care au fost realizate le face pe fiecare în parte, și în ansamblul lor, unicate pentru lumea antică.

Piesele reprezintă creaţii originale ale artizanilor daci şi au în consecință o valoare exceptională nu doar prin conţinutul impresionant în aur de bună calitate ci şi prin contribuţia uriaşă pe care studierea lor o va aduce la împlinirea cunoştinţelor noastre în domeniul artei, a religiei şi a civilizaţiei dacice în ansamblul său.

Socotim că ele aparţin Patrimoniului Cultural Naţional şi trebuiesc incluse in categoria TEZAUR.

VI.

În baza Ordinului Ministrului Culturii şi Cultelor din 6 noiembrie 2008 Comisia de experţi formată din:

1) dr. Eugen Iaroslavschi, CŞI la Muzeul Naţional de Istorie a Transilvaniei din ClujNapoca,

2) dr. Daniel Spânu, CŞIII la Institutul de Arheologie "Vasile Pârvan" al Academiei Române,

3) dr. Gheorghe Trohani, cercetător ştiinţific I la Muzeul Naţional de Istorie a României, a efectuat în perioada 12-15 noiembrie 2008 o deplasare la Frankfurt am Main, Germania, în vederea expertizării a două brăţări plurispiralice din aur ce fac probabil parte din lotul de brăţări dacice din aur descoperit în 
punctul Căprăreaţa din apropierea Sarmizegetusei Regia, capitala Daciei.

Raportul, redactat în prezenţa d-nei expert internaţional dr. Barbara DeppertLippitz, consemnează:

a. Brătara nr. 10-din aur, având 8 spirale, o înălţime de $13 \mathrm{~cm}$, diametrul la exterior, la capete, de $10,8-11 \mathrm{~cm}$, diametrul barei ce are o secţiune rotundă de $5,2-5,5$ mm, o lungime totală desfăşurată de 2,49 m şi o greutate de 1.047,06 grame.

Cele două extremităţi redau stilizat o protomă de animal ce are botul alungit, tăiat drept, iar marginile, fălcile, teşite oblic. Partea mediană a capului şi a coamei este marcată punctiform, decorul fiind identic pe cele două părţi rezultante. Pe frunte sunt două linii de puncte trasate curb între două linii incizate. Ochii sunt redaţi printr-un cerc mic, incizat, cu un punct în mijloc, sprâncenele printr-o mică linie incizată, curbă, iar dinţii printr-o linie punctiformă. Lungimea capului este de $3 \mathrm{~cm}$.

În continuarea capului se află o placă dreptunghiulară cu marginile supraînălţate şi decorate cu două şiruri de mici linii incizate dispuse oblic, în formă de ,V”, despărţite de o linie mediană. Marginea exterioară a uneia dintre extremităţi are aceste linii dispuse în aceeaşi direcţie, nu în „V”. Lungimea celor două plăci dreptunghiulare este de $3,3-3,5 \mathrm{~cm}$.

În continuarea fiecărei plăci dreptunghiulare se află, pe o lungime de $14,2-14,7 \mathrm{~cm}, 7$ palmete cordiforme obţinute cu ajutorul a două stanţe —o primă stanţă pentru 6 palmete şi o a doua pentru a 7-a, mai mică. Decorul este frunziform. Între palmete se află câte un mic cerc cu punct în mijloc obţinut cu ajutorul unui poanson. Marginile palmetelor sunt supraînălţate şi decorate, prin incizie, $\mathrm{cu}$ linii mici dispuse oblic. De asemenea, un decor de linii incizate, ondulate, se află în lungul palmetelor, pe cant.

După ultima palmetă, cea mai mică, pe o lungime de $3,5-3 \mathrm{~cm}$, corpul barei brăţării conţine două porţiuni în formă de perlă alungită (bitronconice), părţile mai subţiri fiind marcate de un grupaj de două linii adâncite, circular transversale.

Începutul corpului propriu zis al brăţării este marcat de o linie în zig-zag care pe una din extremităţile brătării înconjoară toată bara, în timp ce pe cealaltă extremitate este prezentă doar pe partea vizibilă

b. Brătara nr. 11-din aur având 7 spirale, o înălţime de $14 \mathrm{~cm}$, diametrul la exterior, la capete, de $10,8-11,3 \mathrm{~cm}$, diametrul barei ce are o secţiune rotundă de 4,5-5,47 mm, o lungime totală desfăşurată de 2,195 m şi o greutate de 825,06 grame.

Cele două extremităţi redau stilizat o protomă de animal ce are botul alungit, tăiat drept. Partea mediană a capului şi a coamei este marcată punctiform, decorul fiind identic pe cele două părţi rezultante. Ochii şi sprâncenele sunt redate prin linii trasate curb-7 spre exterior şi 6 spre interior. Dinţii sunt redaţi prin câte o linie punctiformă pe cele două laturi ale capului. Lungimea capului este de $2,5 \mathrm{~cm}$.

În continuarea capului se află o placă dreptunghiulară cu marginile supraînălţate şi decorate cu două șiruri de mici linii incizate dispuse oblic, în formă de ,V", despărţite de o linie mediană. Lungimea celor două plăci dreptunghiulare este de 4,9-5,1 cm.

În continuarea fiecărei plăci dreptunghiulare se află, pe o lungime de $11,6-12,4 \mathrm{~cm}, 6$ palmete triunghiulare $\mathrm{cu}$ laturile arcuite obţinute cu ajutorul a trei stanţe -o primă stanţă pentru 3 palmete mai mari, o a doua pentru 2 palmete mijlocii şi o a treia pentru cea mai mică. Decorul este frunziform. Marginile palmetelor sunt supraînălţate şi decorate, prin incizie, cu linii mici dispuse oblic.

După ultima palmetă, cea mai mică, pe o lungime de $2-3 \mathrm{~cm}$, corpul barei brăţării conţine o porţiune în formă de perlă alungită (bitronconică), părţile mai subţiri fiind marcate de un grupaj de trei linii adâncite, circular transversale. De asemenea, un decor de trei linii incizate, ondulate, se află în lungul palmetelor, pe cant.

Pe alocuri se păstrează urme din pământul în care brăţara a fost depusă. Particulele de pământ vor putea fi supuse unor viitoare analize pedologice.

Constatăm că toate cele două brăţări descrise mai sus au multe asemănări cu cele anterior descoperite şi aflate deja în România. 
Au aceeaşi caracteristică fiind confecţionate din aur masiv, ce urmează a fi titrat în laboratoare de specialitate. Chiar dacă nu suntem în posesia unor date precise putem afirma că aspectul exterior este acelaşi cu cel al brăţărilor deja analizate sub acest aspect. Şi aceste brăţări au porţiunile terminale în formă de capete de şarpe, iar continuarea porţiunii decorate $\mathrm{cu}$ diverse incizii sugerează mişcarea şerpuită, alunecarea reptilei. Însăşi forma plurispiralică a brăţărilor vine să confirme ideea aceasta.

Constatăm că brăţara nr. 11 se aseamănă cu cea purtând numărul 8 care are doar de şase ori aplicat decorul în formă de palmetă. Credem că este prematur să facem speculaţii pe această temă şi sperăm că vom avea în curând posibilitatea să analizăm şi alte asemenea artefacte, abia apoi îndrăznind să facem anumite încheieri. În orice caz este de reamintit că situaţia numărului inegal de palmete aplicate pe brăţări se constată şi în cazul celor făcute din argint.

O altă caracteristică a brățărilor expertizate este faptul că nu poartă urmele unei întrebuinţări. Decorul nu este afectat de eroziune, iar porţiunile fie ele stanţate, fie doar ciocănite dovedesc că meşterul nu a fost preocupat de cizelare şi lustruire în nici un caz.

Decorul a fost aplicat doar pe porţiunea exterioară, vizibilă, a pieselor în vreme ce spre interior meșterul a ignorat complet posibilitatea înlăturării urmelor baterii.

Ca o opinie de moment socotim că piesele provin dintr-un atelier comun, eventual fiind opera aceluiaşi meşter care a fost, desigur, ajutat de unele calfe. Perioada în care au fost bătute piesele nu a fost una prea îndelungată în timp, ba din contra, am zice, că ele au fost lucrate într-un interval scurt de timp.

Cele două piese descrise acum fac parte din acelaşi lot cu cele expertizate anterior. Sunt dacice şi provin din zona capitalei Daciei, Sarmizegetusa Regia.

Fie că au aparţinut unui rege dac, fie că au jucat un rol major în anumite ceremoniale cu caracter sacru, ce se desfăşurau în sanctuarele dacice, brăţările au o importanţă deosebită şi suntem convinşi că ele vor deveni adevărate repere pentru specialiştii care vor putea reanaliza în totalitate stadiul cunoştinţelor noastre despre fascinanta civilizaţie a daco-geţilor. Ele vor constitui un adevărat punct de cotitură pentru istoriografia lumii antice din această parte a Europei.

Greutatea lor deosebită, materialul din care sunt confecţionate, felul în care au fost realizate le face pe fiecare în parte, şi în ansamblul lor, unicate pentru lumea antică.

Piesele reprezintă creaţii originale ale artizanilor daci şi au în consecinţă o valoare excepţională nu doar prin conţinutul impresionant în aur de bună calitate, ci şi prin contribuţia uriaşă pe care studierea lor o va aduce la împlinirea cunoştinţelor noastre în domeniul artei, a religiei şi a civilizaţiei dacice în ansamblul său.

Socotim că ele aparţin Patrimoniului Cultural Naţional şi trebuiesc incluse in categoria TEZAUR.

$*$

$\mathrm{Cu}$ respectiva ocazie, în prezenţa d-nei expert internaţional dr. Barbara DeppertLippitz, Comisiei i-a fost prezentată o brăţară din aur de către domnul W. Jackson Helm din Statele Unite ale Americii, însoţit de avocatul său, Thomas Rohrbach.

Brătara nr. 12-din aur, are 10 spirale, o înălţime de $15 \mathrm{~cm}$, diametrul la exterior, la capete, de $9 \mathrm{~cm}$. Diametrul barei are 0 secţiune rotundă de $5 \mathrm{~mm}$, o lungime totală desfăşurată de $2,63 \mathrm{~m}$ şi o greutate de 884,37 grame.

Cele două extremităţi redau stilizat o protomă de șarpe ce are botul alungit, tăiat drept. Partea mediană a capului şi a coamei este marcată punctiform, decorul fiind identic pe cele două părţi rezultante. Ochii şi sprâncenele sunt redate prin linii trasate curb-6 spre linii spre exterior şi 7 spre interior, prima linie, atât la exterior cât şi la interior, fiind redată prin puncte. Lungimea capului este de $2,2-2,3 \mathrm{~cm}$.

În continuarea capului se află o placă dreptunghiulară cu marginile supraînălţate şi decorate cu două şiruri de mici linii incizate dispuse oblic, în formă de ,V”, despărţite de o linie mediană. Lungimea celor două plăci dreptunghiulare este de $3,4-3,7 \mathrm{~cm}$. 
În continuarea fiecărei plăci dreptunghiulare se află, pe o lungime de 14,3$14,6 \mathrm{~cm}, 6$ palmete triunghiular-ovale obţinute $\mathrm{cu}$ ajutorul a trei stanţe $\longrightarrow$ stanţă pentru primele trei palmete, o a doua stantă pentru următoarele două palmete şi a treia stanţă pentru ultima palmetă, cea mai mică. Decorul este frunziform. Marginile palmetelor sunt supraînălţate şi decorate, prin incizie, cu linii mici dispuse oblic. Diferenţele dintre stanţe sunt minimale dar sesizabile. În cazul primei stanţe nervura mediană prezintă 5 bumbi, în timp ce în cazul următoarelor două stanţe nervurile mediane prezintă câte 6 bumbi. Diferenţa dintre stanța a doua şi a treia constă în spaţierea diferenţiată a bumbilor. Stanţa 2 are o spaţiere mai mare a ultimilor doi bumbi, iar la stanţa 3 primul şi ultimul bumb sunt mai spaţiaţi.

După ultima palmetă corpul barei brăţării conţine o porţiune de forma unei perle alungite (bitronconică), părţile mai subţiri fiind marcate de un grupaj de trei linii adâncite, circular transversale, foarte apropiate între ele.

Pe alocuri se păstrează urme din pământul în care brăţara a fost depusă. Particulele de pământ vor putea fi supuse unor viitoare analize.

Prin caracteristicile tehnice, prin morfologia şi sistemul ei ornamental, brăţara este autentică şi se aseamănă cu celelalte exemplare deja achiziţionate de statul român. Brăţara poate fi deci încadrată în categoria Tezaur. Deşi nu dispunem încă de analize metalografice, se poate considera că şi această brăţară a fost realizată din aur aluvionar. Viitoare analize metalografice ar putea confirma această presupunere.

În concluzie, toţi membrii comisiei sunt de acord că această brățară este autentică, face parte din tezaurul cultural naţional şi consideră că recuperarea ei de către statul român este obligatorie.

VII.

În baza Ordinului Nr. 2104 al Ministrului Culturii şi Patrimoniului Naţional din 28 februarie 2011 o Comisie de experţi formată din:
1) prof. dr. Mircea Babeş, CŞ I (Institutul de Arheologie „Vasile Pârvan" al Academiei Române din București),

2) dr. Cristian Gâzdac, CŞ (Institutul de Arheologie şi Istoria Artei din Cluj-Napoca),

3) dr. Gheorghe Trohani, CŞ I (Muzeul Naţional de Istorie a României),

a efectuat în perioada 14-18 martie 2011 o deplasare la Frankfurt am Main, Germania, în vederea expertizării, în prezenţa d-nei expert internaţional dr. Barbara Deppert-Lippitz, a următoarelor obiecte:

A) una brăţară plurispiralică din aur identificată ca făcând parte din lotul de brățări dacice din aur descoperit în zona Sarmizegetusei Regia, capitala Daciei preromane.

B) două piese discoidale, din fier, probabil garnituri ornamentale (umbo) pentru scuturi de paradă sau pentru componente de arhitectură din lemn (mai departe numite convenţional „scuturi”).

C) un lot de 220 monete Koson din argint.

\section{Pentru aceste piese s-a redactat următorul Raport:}

\section{A. Brătară plurispiralică din aur}

Brăţara a fost numerotată în continuarea celor 12 (douăsprezece) brăţări recuperate până în prezent de către Statul Român şi care se află la Muzeul Naţional de Istorie a României din București, căpătând numărul de ordine 13. După informaţiile deţinute ea a fost achiziţionată în anul 2006 la München (expoziţia Numismata) de un colecţionar bulgar, care o oferă Statului Român contra unei compensaţii.

Brătara nr. 13 - din aur având 6,5 spirale, o înălţime de $9 \mathrm{~cm}$, diametrul la exterior, la capete, de 10,5-11,5 cm, diametrul barei ce are o secţiune rotundă de 5,6-5,9 mm, o lungime totală desfăşurată de 2,51 m şi o greutate de 933,4 grame.

Cele două extremităţi redau stilizat o protomă de animal ce are botul alungit, tăiat drept. Partea mediană a capului şi a coamei este marcată prin linii oblice incizate, decorul fiind identic pe cele două părţi rezultante. Ochii şi sprâncenele sunt redate prin câte trei linii trasate curb. Dinţii, canini-colţi, sunt 
redaţi prin câte o linie arcuită, incizată pe cele două laturi ale capului. Lungimea capetelor este de $2-2,1 \mathrm{~cm}$.

În continuarea capului se află o placă dreptunghiulară cu marginile supraînălţate şi decorate cu două şiruri de mici linii incizate dispuse oblic, în formă de „V”, despărţite de o linie mediană. Partea centrală a plăcii este decorată cu o linie punctiformă mediană din care pornesc 13 , respectiv 14 linii oblice, paralele, în „,V”, ale căror limite exterioare sunt punctiforme şi dispuse pe câte o linie incizată, paralelă cu cea mediană și marginile supraînălțate. Lungimea celor două plăci dreptunghiulare este de 3,4-3,62 cm.

În continuarea fiecărei plăci dreptunghiulare se află, pe o lungime de 14,2 $\mathrm{cm}, 7$ palmete triunghiulare cu laturile arcuite obţinute cu ajutorul a două stanţe - o primă stanţă pentru cele 6 palmete mai mari şi o a doua pentru cea mai mică. Decorul este frunziform. Marginile palmetelor sunt supraînălţate şi decorate, prin incizie, cu linii mici dispuse oblic.

De asemenea, un decor de trei linii incizate, ondulate, se află în lungul palmetelor, pe cant.

S-a putut observa că pe alocuri suprafaţa brăţării este acoperită cu o patină translucidă, de culoare uniformă, uşor maronie, care atenuează strălucirea naturală a aurului prelucrat mecanic, situaţie constatată şi la brăţările descoperite anterior.

Pe alocuri se păstrează urme din pământul în care brăţara a fost depusă. Particulele de pământ vor putea fi supuse unor viitoare analize pedologice.

\section{B. „Scuturi" de paradă, dacice, din fier} „scutul” nr. 1 (cu reprezentare zimbru)realizat dintr-o tablă de fier cu diametrul maxim actual de $42 \mathrm{~cm}$ prin prelucrare în tehnica au repoussé, sau mai curând prin batere la cald, având o grosime de 1-1,8 mm şi o înălţime maximă de $5 \mathrm{~cm}$ şi o greutate de circa $1,5 \mathrm{~kg}$. Pe toată circumferinţa exterioară este reprodusă o bandă gen şnur sau funie răsucită, în relief, lată de $5 \mathrm{~mm}$, ce delimitează la exterior o margine plată (,borul”) a piesei, lată de $5 \mathrm{~cm}$ şi perforată în zona mediană cu 12 orificii rotunde, cu diametrul de $6,7-7,1-7,8-8,75 \mathrm{~mm}$, uneori deformate din cauza vechimii şi a restaurării, situate la distanţe relativ egale între-ele (8,95-10,11 cm din centrul orificiului).

Această margine plată (,bor”) delimitează umboul propriu zis al scutului compus din trei registre, toate decorate:

a) registrul nr. 1 (decor Eierstab) se compune din ove mici $(1,5-0,93 \mathrm{~cm})$ ce au partea rotunjită spre exterior, iar partea dinspre interior este dreaptă, sprijinindu-se pe o bandă gen funie răsucită, în relief, lată de 5 mm. Ovele sunt înconjurate pe trei părţi de o linie ovală, paralelă, în relief. Între ove se află câte 2 linii paralele, în relief. Lungimea ovelor, pe o linie oblică, este de $1,87 \mathrm{~cm}$. iar lăţimea unei ove este de $1,62 \mathrm{~cm}$.

b) registrul 2 , lat de $4,5 \mathrm{~cm}$, este delimitat de două benzi gen funie răsucită, în relief, late de $5 \mathrm{~mm}$. Funia exterioară este cea ce delimitează acest registru de cel anterior, iar funia interioară marchează delimitarea de registrul 3, medalion central. Cele două funii au înfăşurarea în acelaşi sens dinspre exterior stânga spre interior dreapta sus. Întreg registrul 2 este decorat cu două şiruri imbricate formate din câte 19 frunze triunghiulare cu nervură mediană şi cu marginile de asemenea marcate în relief. În planul secundar se văd doar vârfurile frunzelor triunghiulare, ce au şi ele nervurile mediane şi marginale. Frunzele stratului superior se văd integral; ele sunt tangente la bază, spre centrul scutului, iar spre exterior au vârfurile distanţate la 4,6-4,8 cm.

c) registrul $3 \mathrm{sau}$,medalionul central" are un diametru de $18,5 \mathrm{~cm}$. Întreg spaţiul acestui medalion central este ocupat de decorul animal şi vegetal ce se descrie mai jos.

În centru se află reprodus, în relief, un zimbru văzut în profil spre dreapta. Capul zimbrului, cu ureche, ochi, nas şi bot, de asemenea în profil, are coarnele văzute din faţă. Sub bărbie se afle o barbă triunghiulară cu vârful în jos. Corpul este decorat cu şiruri de linii scurte incizate, paralele, ce redau blana (părul). Pe picioare liniuţele sunt orientate dreapta sus-stânga jos, în conformitate cu conturul piciorului. Părul de pe coadă, ce atârnă în jos, este redat ca un sfredel. Picioarele sunt în mers, unul în faţa celuilalt _doar piciorul stâng din spate fiind îndoit. Picioarele de pe partea stângă sunt 
înspre înainte, iar cele de pe partea dreaptă sunt întinse spre înapoi. La picioarele din spate se observă o dublură a liniei de contur spre spate sub formă de adâncitură şi crestături. Copitele sunt despicate -mai vizibil la picioarele posterioare.

În spatele şi deasupra zimbrului se dezvoltă o iederă lungă, ondulată, din care se separă alte trei ramuri terminate cu trei frunze de dimensiuni diferite ornate prin haşurare. $\mathrm{O}$ a patra ramură se termină cu un cârcel, în spirală.

La coada taurului se află, foarte probabil, tulpina vrejului, reprezentată tot ca un sfredel, ea fiind paralelă cu coada.

O altă ramură, tot cu trei frunze, porneşte din fał̧a piciorului stâng anterior, ondulându-se prin spaţiul de sub şi din faţa botului animalului, terminându-se în dreptul coarnelor. După prima curbă, sub botul animalului, atârnă o frunză de iederă ornată cu linii adâncite, haşurate. Zona din dreptul frunţii animalului este prost conservată rugină şi porţiuni lipsă. Zimbrul calcă pe o plantă cu trei tulpini înflorate -florile de pe tulpinile exterioare, amplasate între picioarele din spate sau sub proiecţia în jos a picioarelor din faţă, fiind redate printr-o eflorescentă de câte 6 puncte în jurul unui punct central (pistil), iar tulpina centrală, sub burta zimbrului, are o eflorescentă de 6 petale ovale. Tijele sunt spiralate şi au câte o ramură fără floare. Toate cele trei tulpini pleacă dintr-o tufă reliefată şi ornată cu striuri verticale.

$\mathrm{Pe}$ spatele piesei, pe margine se observă o şănţuire ce reprezintă negativul marginii reliefate de pe exterior. La fel funiile ce separau registrele 1, 2 și 3 apar sub forma unor şănţuiri. Se observă, de asemenea adânciturile (negativul) întregului decor.

Relieful (înălţimea) elementelor decorative măsurate de la baza de fixare a „borului” plat:

Umărul zimbrului: $+4,62 \mathrm{~cm}$.

Adâncimea şnurului sau funiei ce separă registrul 2 de $3:+2,79 \mathrm{~cm}$.

Adâncimea şnurului sau funiei ce separă registrul 1 de $2:+1,77 \mathrm{~cm}$.

Adâncimea fondului registrului 3 , în câmp deasupra animalului: $+2,87 \mathrm{~cm}$.

\section{„2Scutul" nr. 2 (cu reprezentare} grifon)-realizat dintr-o tablă de fier cu diametrul de $41,8 \mathrm{~cm}$ prin prelucrare în tehnica au repoussé, sau mai curând prin batere la cald, având o grosime de 1,8-1,9 $\mathrm{mm}$ şi o înălţime maximă de $5 \mathrm{~cm}$. şi o greutate de circa $1,6 \mathrm{~kg}$. Pe toată circumferinţa exterioară este reprodusă o bandă gen şnur sau funie răsucită, în relief, lată de 5,73-6,2-6,7 mm, ce delimitează marginea plată (,,borul'), lată de 4,6-4,8-5 $\mathrm{cm}$ şi perforată în zona mediană cu 12 orificii rotunde, uneori deformate din cauza vechimii şi a restaurării —unele fiind pătrate, ovale sau alte forme neregulate, având un diametru de 5,6-8,3-9,2 mm, situate la distanţe relativ egale între ele $(8,42-9,84 \mathrm{~cm}$ din centrul orificiului).

Pe partea superioară a piesei, în centru, s-a păstrat un cui-floare de prindere. Diametrul este de $4,32 \mathrm{~cm}$ şi reprezintă probabil o rozetă cu petale ovale, alungite. Cuiul străpunge bordura şi iese pe spate.

Spre dreapta, la $6 \mathrm{~cm}$, se păstrează, probabil, urmele unui alt cui dispărut.

Pe această parte a ,scutului”, tangentă cu registrul 1, se observă o îndoitură de 30 40 grade, cauzată probabil de smulgerea obiectului de pe un suport de lemn. Distanţa este de 3 cuie. Deformarea continuă însă spre dreapta încă pentru două cuie provocând o îndoire, chiar rupere, a borului. Prin urmare deformarea cuprinde cam o treime din bor.

Această margine plată („bor”) delimitează umboul propriu zis al „scutului” compus din trei registre, toate decorate:

a) registrul nr. 1 (decor Eierstab) se compune din ove mici $(1,5-0,93 \mathrm{~cm})$ ce au partea rotunjită spre exterior, iar partea dinspre interior este dreaptă, sprijinindu-se pe o bandă gen şnur sau funie răsucită, în relief, lată de 5 mm. Între ove se află câte 2 linii paralele, în relief. Lungimea ovelor, pe o linie oblică, este de $1,87 \mathrm{~cm}$. Iar lăţimea de $1,62 \mathrm{~cm}$.

b) registrul 2 , lat de $4,5 \mathrm{~cm}$, este delimitat de două benzi gen şnur sau funie răsucită, în relief, late de $5 \mathrm{~mm}$. Şnurul exterior este cel ce delimitează acest registru de cel anterior, iar şnurul interior marchează delimitarea de registrul 3, medalion central. Cele două şnururi sau funii au înfăşurarea în acelaşi sens dinspre exterior stânga spre interior dreapta sus. Întreg registrul 2 este decorat cu două şiruri imbricate de câte 19 frunze 
triunghiulare cu nervură mediană şi cu marginile de asemenea marcate în relief. În planul secundar se văd doar vârfurile frunzelor triunghiulare, ce $\mathrm{nu}$ au nervuri mediane ci numai marginale, pe cele două laturi ale vârfului. Spre exterior au vârfurile distanţate la $4,6-4,8 \mathrm{~cm}$. Frunzele mari lasă loc bazei frunzelor mici.

c) registrul 3 sau ,medalionul central" are un diametru de $18,6 \mathrm{~cm}$.

În centru se află deasupra diametrului maxim un grifon în profil spre dreapta cu corp şi labe de leu, gât, cap şi aripi de pasăre răpitoare.

Capul redă o protomă de pasăre răpitoare cu capul ridicat, cioc încovoiat, ochii realizaţi punctual şi cu o ureche îndreptată înainte. Din zona de contact dintre piept şi labele din faţă pomeşte o nervură, arcuită în relief puternic, ce reprezintă aripa dreaptă. Ea suprapune în bună măsură gâtul animalului pentru a coti apoi brusc spre spate pe un duct arcuit. Vârful aripii se termină dincolo de fundul şi coada animalului. Penajul este reprezentat în prima parte $-2,6-4,3 \mathrm{~cm}-$ prin pene semicirculare, late. Apoi continuă până la vârful cozii prin 16 benzi haşurate alternativ, 2-4 mm, cu lungimi variabile $-6,5$ $\mathrm{cm}$ la marginea de sus până la $0,8 \mathrm{~cm}$ la gât. Prima nervură, ce conturează exteriorul aripii, are şi haşuri în formă de ,V'.

Corpul animalului, decorat cu linii subţiri, incizate, trasate oarecum neregulat, este arcuit, încordat, puternic reliefat. Labele din faţă sunt întinse înainte ca la un salt - cea din stânga îndoită, iar cea din dreapta întinsă. Labele din spate sunt: dreapta rămasă în urmă, stânga flexată spre înainte. Ghearele şi labele sunt marcate prin câte două şănţuiri adâncite la fiecare picior.

Coada este îndoită în formă de ,S" cu vârful în jos.

Câmpul rămas liber sub corpul animalului este umplut de un decor vegetal după cum urmează: pornind din marginea funiei sunt două frunze desfăcute din care pleacă spre stânga un vrej scurt terminat în spirală (între labele din spate ale animalului) şi un vrej gros cu tulpina răsucită oblic, din care se despart un vrej scurt spre burta animalului, un vrej scurt terminat în frunză de iederă sub laba dreaptă din faţă a animalului, şi un vrej scurt terminat cu o frunză căzând în jos spre marginea medalionului.

Între ultimele două frunze, în câmp, este redată în relief o floare cu bumb central (pistil) şi patru petale triunghiulare, fără vrej.

Pe revers se observă şănţuirea corespunzătoare marginii reliefate şi crestate a borului, cele două adâncituri concentrice ale funiilor dintre registrele $1-2$ şi $2-3$. Se observă, de asemenea adânciturile (negativul) întregului decor.

Relieful (înălţimea) elementelor decorative măsurată de la baza de zacere a piesei („,borul”):

Coapsa animalului : $+4,3 \mathrm{~cm}$.

Umărului: $+4,52 \mathrm{~cm}$.

Laba din faţă: $+3,7 \mathrm{~cm}$.

Marginea de sus a aripii: $+3,49 \mathrm{~cm}$.

Tufa plantei este la $3,85 \mathrm{~cm}$.

Funia primă: $+1,51 \mathrm{~cm}$.

Funia secundă: $+2,8 \mathrm{~cm}$.

Deformarea (îndoitura) maximă a borului este la $2,57 \mathrm{~cm}$, iar în dreptul cuiului la $2 \mathrm{~cm}$.

\section{Monete dacice}

Dintru început se remarcă că în Dispoziţia pe baza căreia s-a făcut deplasarea se specifică efectuarea unei expertize pe un lot de 220 monete de tip Koson din argint. Ori la faţa locului s-a constatat că numărul real este de 229 monete dintre care 27 sunt din aur de tip Lysimachos sau PseudoLysimachos, 39 din argint de tipul Koson „clasic" şi 163 din argint de tipul Koson Droyeis (?).

Aceste monete fac parte din două loturi distincte.

a) Monetele din argint sunt parte a unui lot de circa 2700 monete descoperite în decembrie 2003 pe Dealul Bodii (Dealul MunceluluiFeţele Albe).

b) Monetele din aur sunt parte a unui lot de 3600 monete de tip Lysimachos, Pharnakes şi Asander descoperite în august 1998 în zona Sarmizegetusa, pe Şesul Căprăreaţei, nu departe de locul descoperirii primelor brăţări plurispiralice din aur. 
Conform Ordinului mai sus amintit membrii Comisiei de specialitate au trebuit să răspundă, printre altele, la următoarele obiective:

1) Ce reprezintă bunurile prezentate?

2) Dacă bunurile respective sunt autentice şi constituie parte dintr-un tezaur ori sunt replici moderne a unor piese autentice ?

3) Din punct de vedere arheologic care este zona de provenienţă a bunurilor ?

4) Stabilirea susceptibilităţii ca respectivele bunuri să fie clasate în patrimoniul cultural naţional.

În cele ce urmează se răspunde pe puncte la cele solicitate.

1) La acest punct am răspuns atunci când am făcut descrierea pieselor, care reprezintă, după cum urmează:

- brățară plurispiralică din aur, similară celorlalte 12 piese recuperate anterior, reprezentând produse de mare calitate şi valoare ale orfevreriei dacice din sec. I a. Chr.

- două piese ornamentale (,scuturi” de paradã) din fier, cu reprezentări zoomorfe şi vegetale, databile, pe baza descoperirii mai vechi de la Piatra Roșie, publicată de C. Daicoviciu, în sec. I a. Chr.

— dintre cele 229 monede, 27 piese din aur aparţin tipului Lysimachos, 39 piese de argint aparțin tipului clasic Koson, iar 163 piese de argint aparţin unui tip nou, cu legenda Koson Droyeis, inspirat iconografic de emisiunile de tip Macedonia Prima; datare: sfârşitul sec. II a. Chr. - mijlocul sec. I p. Chr.

2) Toate piesele sunt autentice, nepunându-se problema ca acestea să fie replici moderne după piese autentice antice. Este posibil ca brăfjara de aur să provină dintr-una din descoperirile colective - tezaure de brățări (de 10 , respectiv 5 piese) sau dintr-o descoperire izolată, cu toate provenind din centrul politic şi religios de la Sarmizegetusa Regia.

După informaţii aflate la dosarul cauzei, cele două umbo de „scuturi” aparţin unei descoperiri colective (depozit de obiecte de fier) constituite din 7 piese.

Autenticitatea celor două piese oferite spre recuperare este confirmată de Raportul de examinare (Examination Report) întocmit de Chase Art Services din SUA la 3 iunie 2003, pe baza studiului radiografic, a analizei chimice şi a metalografiei. Din acelaşi raport, ca şi din aspectul lor actual rezultă că piesele au fost curăţate şi restaurate în laborator şi că dintr-una din ele a fost luată o mică probă de metal.

Monedele de aur au aparţinut unui tezaur compus din 3600 monede (descoperit în 1998), iar cele de argint au făcut parte dintr-un alt tezaur, compus din 2700 de monede (descoperit în 2003).

3) Din punct de vedere arheologic, având în vedere descoperirile certe anterioare, zona de provenienţă a tuturor obiectelor în discuţie brăţara plurispiralică din aur, cele două scuturi din fier şi cele 229 monete din aur şi argint- este regiunea Munţilor Orăștiei, respectiv ansamblul cetăţilor dacice din jurul Sarmizegetusei.

a) Având în vedere răspândirea celor circa 30 de brăţări spiralice de argint dacice cunoscute (28 în România, una în Serbia şi una în Bulgaria), precum şi a celor 12 brăţări plurispiralice similare, din aur, cunoscute şi recuperate până în prezent, se poate presupune cu maximă probabilitate că şi brăţara plurispiralică din aur nr. 13, expertizată de noi, provine din spaţiul Daciei preromane, mai precis din centrul regatului dac situat în Munţii Orăştiei. Fiind vorba de un exemplar de o deosebită frumuseţe, fiind din aur şi cântărind în jurul a un kilogram $(933,4$ g), brățara nr. 13 reprezintă o parte dintr-un tezaur regal ascuns în împrejurimile Sarmizegetusei Regia, capitala politică, militară şi spirituală a Daciei. Ea nu poate proveni dintr-o așezare obişnuită şi nici dintro descoperire funerară.

Din izvoarele istorice scrise se ştie că Decebal şi-a ascuns tezaurul regal în râul Sargetia, probabil într-un gest cu semnificaţie cultică; ştiut fiind că centrul religios al dacilor se afla la Sarmizegetusa Regia, este de avut în vedere posibilitatea ca astfel de obiecte preţioase, precum brăţara nr. 13 , să fi fost depuse ca ofrandă zeilor.

Brăţările plurispiralice din aur reprezintă creaţii originale ale artizanilor daci şi au în consecinţă o valoare excepţională nu doar prin conţinutul impresionant în aur, ci şi 
prin importanta contribuţie pe care studierea lor o va aduce la îmbogăţirea cunoştinţelor noastre în domeniul artei, a religiei şi a civilizaţiei dacice în ansamblul său.

b) „Scuturi” din fier —până de curând în România se cunoştea doar un singur exemplar descoperit în cetatea de la Piatra Roşie (săpături C. Daicoviciu, 1949; publicaţie 1954) - decorat în medalionul central cu un taur după unele interpretări sau cu un zimbru, după părerea noastră și asupra căruia se poartă astăzi diverse discuţii privind modalitatea lui de restaurare.

În Muzeul de Istorie al Transilvaniei din Cluj se mai află un „scut” fragmentar din fier, inedit, descoperit — se pare - în aceleaşi condiţii cu piesele examinate de noi, şi cu alte patru piese similare, sustrase prin săpături ilegale. Este vorba deci de 7 ,scuturi" din fier -cu reprezentări de zimbru sau taur, grifon, felină (panteră?) şi leu- dintre care 6 „scuturi” ce se află în prezent în străinătate, date în urmărire de către organele românești abilitate. Primele două sunt cele examinate de noi, expertizare de Chase Art Services în 2003. Celelalte 4 piese sunt, se pare, cu toate în proprietatea firmei Freeman \& Sear din Los Angeles. Imaginile a două dintre acestea, aflate în urmărire, figurează şi în volumul Patrimonium II. Combaterea Criminalitătii contra Patrimoniului Cultural European, apărut la Cluj-Napoca în 2009, pagina 473. Având în vedere cercetările lui C. Daicoviciu din anul 1949, locul cel mai probabil de descoperire este cetatea dacică de la Piatra Roșie.

c) În privinţa monetelor ele fac parte din două loturi distincte (tezaure), cu locuri de descoperire fixate prin investigaţiile organelor judiciare în împrejurimile Sarmizegetusei Regia, capitala Daciei, după cum urmează:

- monetele din argint sunt parte a unui lot de circa 2700 monete descoperite în decembrie 2003 pe Dealul Bodii (Dealul MunceluluiFeţele Albe).

- monetele din aur sunt parte a unui lot de 3600 monete de tip Lysimachos şi Phamakes descoperite în august 1998 în zona Sarmizegetusa, pe Şesul Căprăreaţei, nu departe de locul descoperirii primelor brăţări plurispiralice din aur.
4) Socotim că toate obiectele expertizate la solicitarea organelor judiciare române, ca fiind excavate ilegal şi sustrase din siturile clasate monument istoric din Munţii Orăştiei, toate aparţinând patrimoniului mondial UNESCO: o brăţară plurispiralică din aur, două scuturi din fier şi 229 monete, aparţin Patrimoniului Cultural Naţional şi trebuiesc incluse in categoria TEZAUR.

Cele două ,scuturi" din fier, prin tehnica superioară de realizare, prin decorul lor complex, cu motive fito- şi zoomorfe şi, nu în ultimul rând, prin scopul pentru care au fost făcute (indiferent că reprezintă decoraţia unor scuturi sau omamente pe porţi de cetate sau de palat) sunt piese de o deosebită valoare artistică şi ştiinţifică. Deşi realizate din fier, prin urmare dintr-un metal comun, prin mesajul pe care îl transmit aceste piese vor deveni exponate de maxim interes muzeistic, iar studiul lor va aduce cu siguranţă noi contribuţii la mai buna cunoaştere a tehnicii antice, a religiei şi artei dacilor, a relaţiilor Daciei preromane cu lumea înconjurătoare -greacă, celtică şi romană. După părerea noastră, în momentul de faţă, după ce avem deja un lot de 12 brăţări plurispiralice din aur, prezenţa acestor două „scuturi” în România se impune ca o prioritate, mai ales că cele două exemplare deja existente în muzeul din Cluj-Napoca se află într-o avansată stare de deteriorare (fragmentare, coroziune).

Lotul de 229 monede, de fapt părţi din două loturi distincte, trebuie şi el recuperat în întregime, dată fiind semnificaţia ştiinţifică cu totul nouă şi remarcabilă a acestor monede; în temeiul drahmelor cu legenda Koson Droyeis va putea fi studiat un nou tip monetar, până acum necunoscut, care a fost emis şi a circulat în Dacia, aducând nebănuite informaţii referitoare la istoria politică, economică şi culturală a acestui spaţiu în epoca pre-romană, mai precis în sec. I a. Chr.

\section{VIII.}

Prin Decizia nr. 125 din 22.10.2007 a Muzeului Naţional de Istorie a României s-a numit o Comisie de experţi formată din:

1) dr. Lucia Marinescu (Muzeul Naţional de Istorie a României, Bucureşti), 
2) dr. George Trohani (Muzeul Naţional de Istorie a României, Bucureşti)

în vederea examinării a două brăţări din aur pe baza a două fotografii.

Spre expertizare au fost prezentate două fotografii color cu câte două brăţări plurispiralice din aur. Piesele au fost examinate pe hârtie şi prin ordinator PS macroscopic.

La întrebările puse de către autorităţile în drept, în ziua de 25 octombrie 2007, s-a răspuns după cum urmează:

1. Descrierea pieselor:

a. Brăţară plurispiralică ce figurează în fotografia 1, la stânga, iar în fotografia 2 la dreapta, constituită dintr-o bandă-tijă cu secţiunea rotundă şi arcuită în 6,5 spirale, din metal galben ce trebuie să fie aur. Se constată o uşoară deformare a spiralelor.

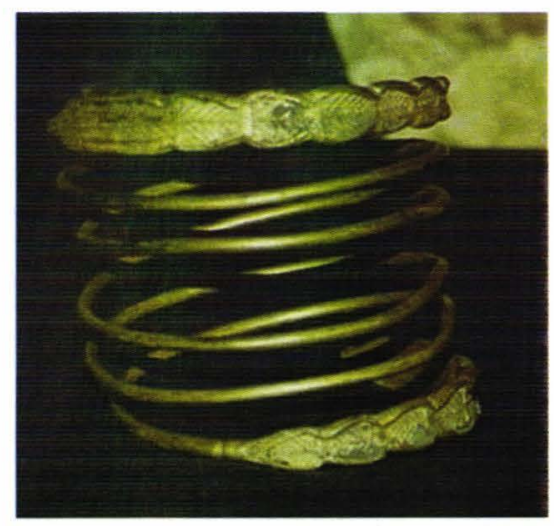

Brăţara (a)

Capetele tijei au fost mai întâi aplatizate, iar apoi acea porţiune a fost împărţită în trei câmpuri distincte. Cel de la extremitate imită într-o formă schematizată un cap de şarpe, apoi urmează o porţiune mai lată, relativ orizontală, constituind o placă dreptunghiulară decorată cu mai multe linii (s-au putut număra 23) oblice incizate în formă de brăduţ, locul de întâlnire a liniilor, de pe mijlocul plăcii, fiind marcat prin incizii punctiforme dispuse liniar. Părţile laterale ale acestei porţiuni sunt uşor supraînălţate.

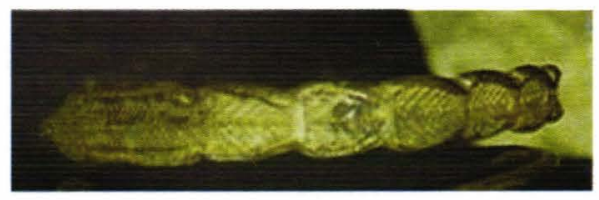

Brăţara (a) detaliu
Cea mai lungă porțiune este decorată cu şapte palmete, imprimate prin ştanţare, care sunt la rândul lor flancate de brâuri supraînălţate, decorate după cât se pare cu linii fine incizate. Numărul de palmete cu care este decorată brăţara este de câte şapte la fiecare din cele două capete. Felul în care sunt ele marcate nu este însă identic. Astfel primele şase palmete sunt realizate cu aceeaşi stanţă, conţinând 5 linii oblice incizate în formă de brăduţ, locul de întâlnire a liniilor, de pe mijlocul palmetei, fiind marcat prin incizii punctiforme dispuse liniar. Urmează apoi a şaptea palmetă realizată cu o stanţă mai mică şi conţinând doar 4 linii oblice incizate în formă de brăduţ, locul de întâlnire a liniilor, de pe mijlocul palmetei, fiind de asemenea marcat prin incizii punctiforme dispuse liniar.

Spaţiul dintre palmete şi corpul tijei este decorat prin două grupe a câte trei linii circulare, incizate.

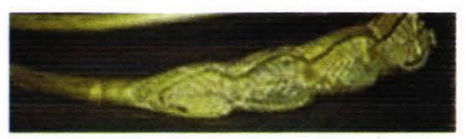

\section{Brățara (a) detaliu corpul tijei}

b. Brăţară plurispiralică ce figurează în fotografia 1 la dreapta, iar în fotografia 2 la stânga, constituită dintr-o bandă-tijă cu secţiunea rotundă şi arcuită în 7,5 spirale, din metal galben ce trebuie să fie aur. Se constată o uşoară deformare a spiralelor.

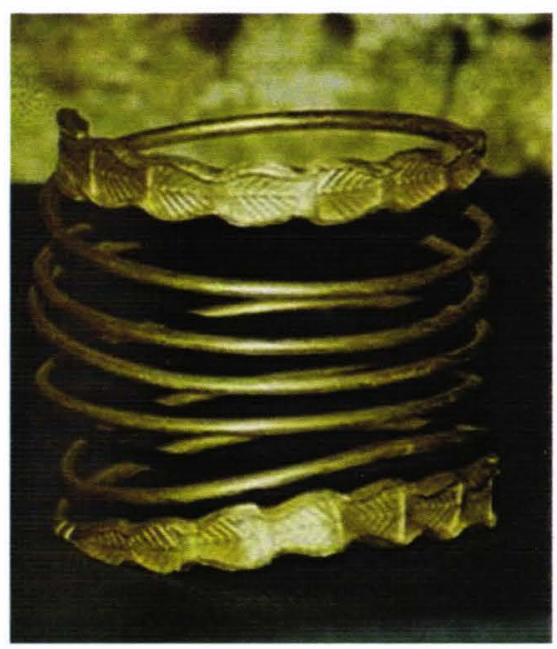

Brăţara (b) 
Capetele tijei au fost mai întâi aplatizate, iar apoi acea porţiune a fost împărţită în trei câmpuri distincte. Cel de la extremitate imită într-o formă schematizată un cap de șarpe, apoi urmează o porţiune mai lată, relativ orizontală, constituind o placă dreptunghiulară decorată cu mai multe linii(sau putut număra 15) oblice incizate în formă de brăduţ, locul de întâlnire a liniilor, de pe mijlocul plăcii, fiind marcat prin incizii punctiforme dispuse liniar. Părţile laterale ale acestei porţiuni sunt uşor supraînălţate şi, la rândul lor, decorate cu scurte linii incizate dispuse în formă de V.

Cea mai lungă porţiune este decorată cu şapte palmete, imprimate prin ştanţare, care sunt la rândul lor flancate de brâuri supraînălţate, decorate după cât se pare cu linii fine incizate. Numărul de palmete cu care este decorată brățara este de câte șapte la fiecare din cele două capete. Felul în care sunt ele marcate nu este însă identic. Astfel primele şase palmete sunt realizate cu aceeaşi stanţă, conţinând 5 linii oblice incizate în formă de brăduţ, locul de întâlnire a liniilor, de pe mijlocul palmetei, fiind marcat prin incizii punctiforme dispuse liniar. Urmează apoi a şaptea palmetă realizată cu o stanţă mai mică și conţinând doar 4 linii oblice incizate în formă de brăduţ, locul de întâlnire a liniilor, de pe mijlocul palmetei, fiind de asemenea marcat prin incizii punctiforme dispuse liniar. Părţile laterale ale palmetelor sunt uşor supraînălţate şi, la rândul lor, decorate cu circa 3 linii incizate dispuse paralel, în lungul palmetelor.

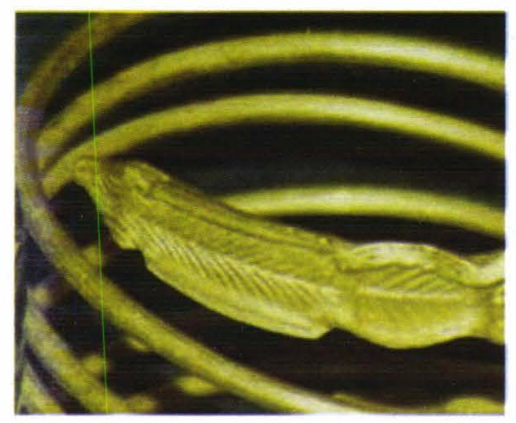

Brățara (b) detaliu

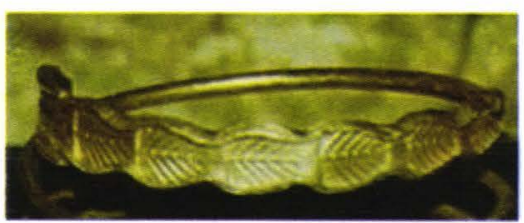

Brățara (b) detaliu palmete

Spaţiul dintre palmete şi corpul tijei este decorat prin două grupe a câte trei linii circulare, incizate.

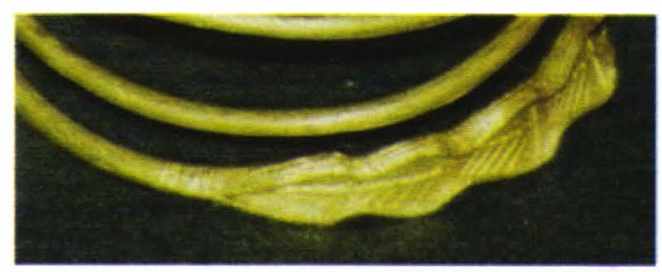

\section{Brățara (b) detaliu corpul tijei}

Prin urmare piesele prezentate sunt două brățări plurispiralice din aur aparţinând unei categorii de podoabe tipic dacice, cunoscută însă anterior exclusiv prin exemplare de argint, databile în secolul I a. Chr. Aceeaşi este şi datarea prezentelor piese din aur. Având în vedere raritatea şi valoarea mare a metalului, dimensiunile mari şi excelenta execuţie, piesele din aur pot fi considerate podoabe și însemne ale puterii în societatea dacică.

2. De la început se impune constatarea unei asemănări şi a acestor două piese examinate, din aur, cu brăţările de formă spiralică, din argint, cunoscute din descoperirile mai vechi de tezaure dacice de podoabe de argint, din epoca geto-dacă clasică (sec. II a. Chr.-I p. Chr.). Pe de altă parte aceste două brățări din aur prezintă aceleaşi caractere cu celelalte nouă brățări din aur recuperate până în prezent ele făcând parte, mai mult ca sigur, din acelaşi lot de obiecte de podoabă.

3. La o analiză macroscopică, pe baza fotografiilor puse la dispoziţie, se poate constata o anumită asemănare între aceste două brăţări (a şi b), examinate în raportul de faţă, cu brăţările 1,3 şi 7 din loturile anterioare.

Însă capul de şarpe al brăţării nr. 1 este diferit redat faţă de cel al brăţărilor a şi b din prezentul raport, numărul liniilor oblice de pe 
placa romboidală este de 17 , iar numărul spiralelor este de 7,5.

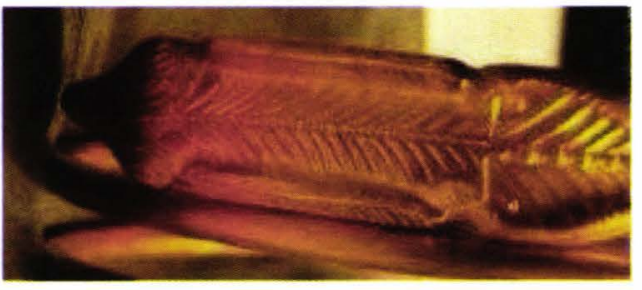

Capul de şarpe al brăţării nr. 1

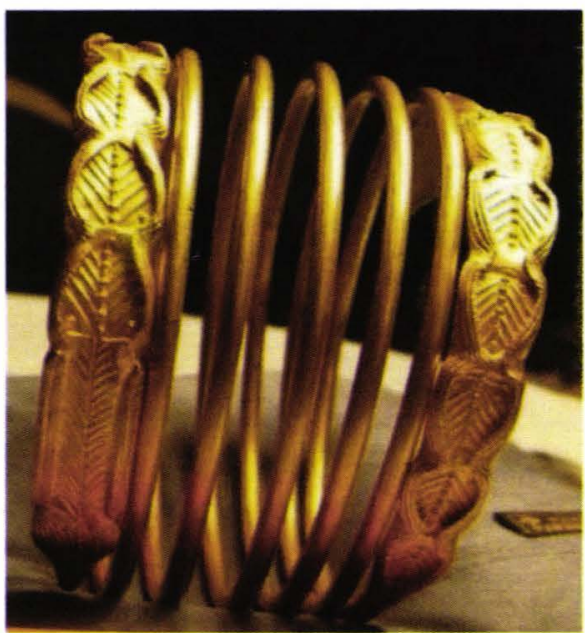

Brățara nr. 1

Brăţara nr. 3 are un număr total diferit de spirale, iar diametrul este mult mai mic.

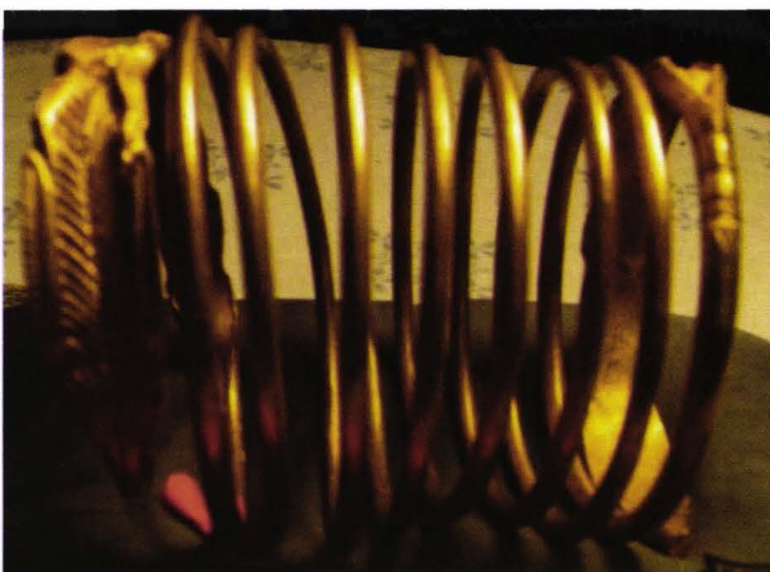

Brățara nr. 3

Brăţara nr. 7 are capul de şarpe asemănător cu brățara a, dar numărul liniilor oblice de pe placa dreptunghiulară este de 12 pe una din jumătăţile plăcii şi de 14 pe cealaltă jumătate. In plus decorul ce continuă după palmete pe corpul tijei este mai complex (brăţara 7.2).

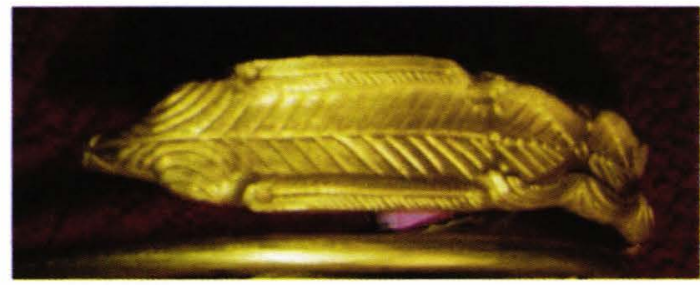

Brăţara 7 detaliu
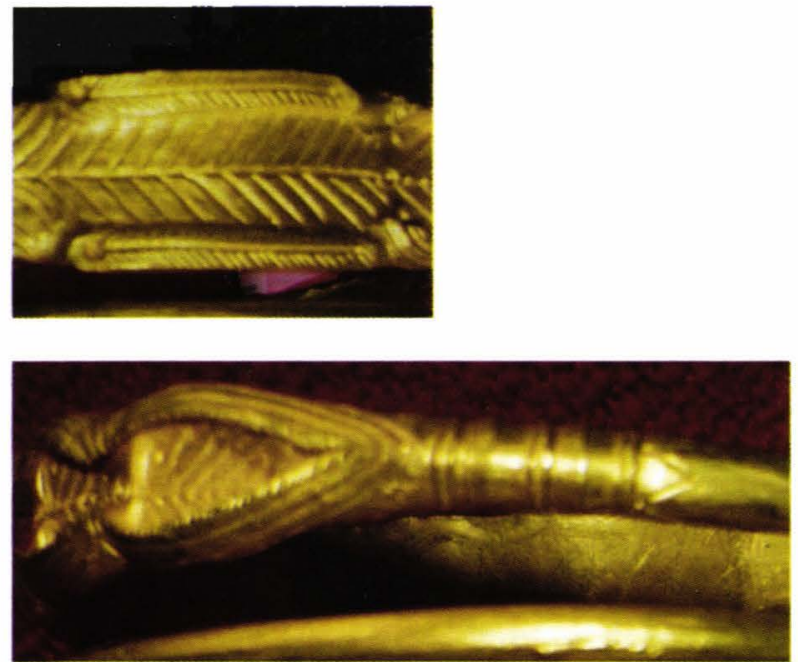

Brățara 7 detaliu corpul tijei

În concluzie, cu rezerva cuvenită dată fiind modalitatea efectuării expertizei, este vorba despre două brăţări ce nu pot fi identificate cu cele nouă deja recuperate.

4. Piesele examinate anterior, atât la Frankfurt, cât şi în Bucureşti, au făcut parte, foarte probabil, dintr-unul dintre aceste două tezaure, localizate de anchetatori în situl arheologic „Căprăreaţa”, din apropierea cetăţii regale dacice Sarmizegetusa - de pe Dealul Grădiştii (Grădiştea Muncelului). Tot din această zonă trebuie să provină şi aceste două brăţări, tot din aur, expertizate în raportul de faţă.

Aceste două brățări de aur examinate prezintă toate caracterele tipologice (formă, ornamentică) ale celor cca. 30 de brăţări spiralice de argint, cunoscute anterior, provenind în marea 
lor majoritate (28 exemplare) de pe teritoriul României, precum şi cu cele nouă din aur expertizate anterior. În chip special se remarcă asemănarea cu exemplarele de argint de la Cărpiniş, Coada Malului, Orăştie şi Senereuş. Asemănarea evidentă dovedeşte că piesele de aur sunt contemporane cu cele de argint și, ca urmare, se datează în perioada secolului I a. Chr. Totodată, analogia ne arată că orfevrarii daci erau capabili să lucreze şi în aur, atunci când comanditarul dorea acest lucru şi putea să livreze materia primă, aurul.

Având în vedere răspândirea celor peste 30 de brățări spiralice de argint dacice cunoscute (28 în România, două în Serbia şi una în Bulgaria), se poate presupune cu maximă probabilitate că şi aceste două brățări din aur, expertizate în raportul de faţă, provin din spaţiul Daciei preromane. Fiind exemplare de o deosebită frumuseţe, fiind din aur, ele pot să reprezinte o parte dintr-un tezaur regal ascuns în împrejurimile Sarmizegetusei Regia, capitala politică, militară şi spirituală a Daciei. Ele nu pot proveni dintr-o aşezare obişnuită.

5. După părerea membrilor comisiei, fiind autentice şi provenind de pe teritoriul României, şi aceste două brăţări examinate în prezentul raport trebuiesc încadrate în inventarul Patrimoniului Cultural Naţional, clasa Tezaur.

PI. 1 - Brățările nr. 1-6.

LISTA ILUSTRAŢIEI

PI. 2 - Brățările nr. 7-12.

PI. 3- 1. Brățara nr. 13; 2. Scutul nr. 1; 3. Scutul nr. 2

EXPLICATION DES FIGURES

Pl. 1 - Les bracelets no. 1-6

Pl. 2 - Les bracelets no. 7-12

Pl. 3-1. Le bracelet no. 13; 2. Le écu no. 1 ; 3. Le écu no. 2

George TROHANI

Muzeul Naţional de Istorie a României

Secția Arheologie

Calea Victoriei 12, 030026, Bucureşti.

gtrohani@yahoo.com 


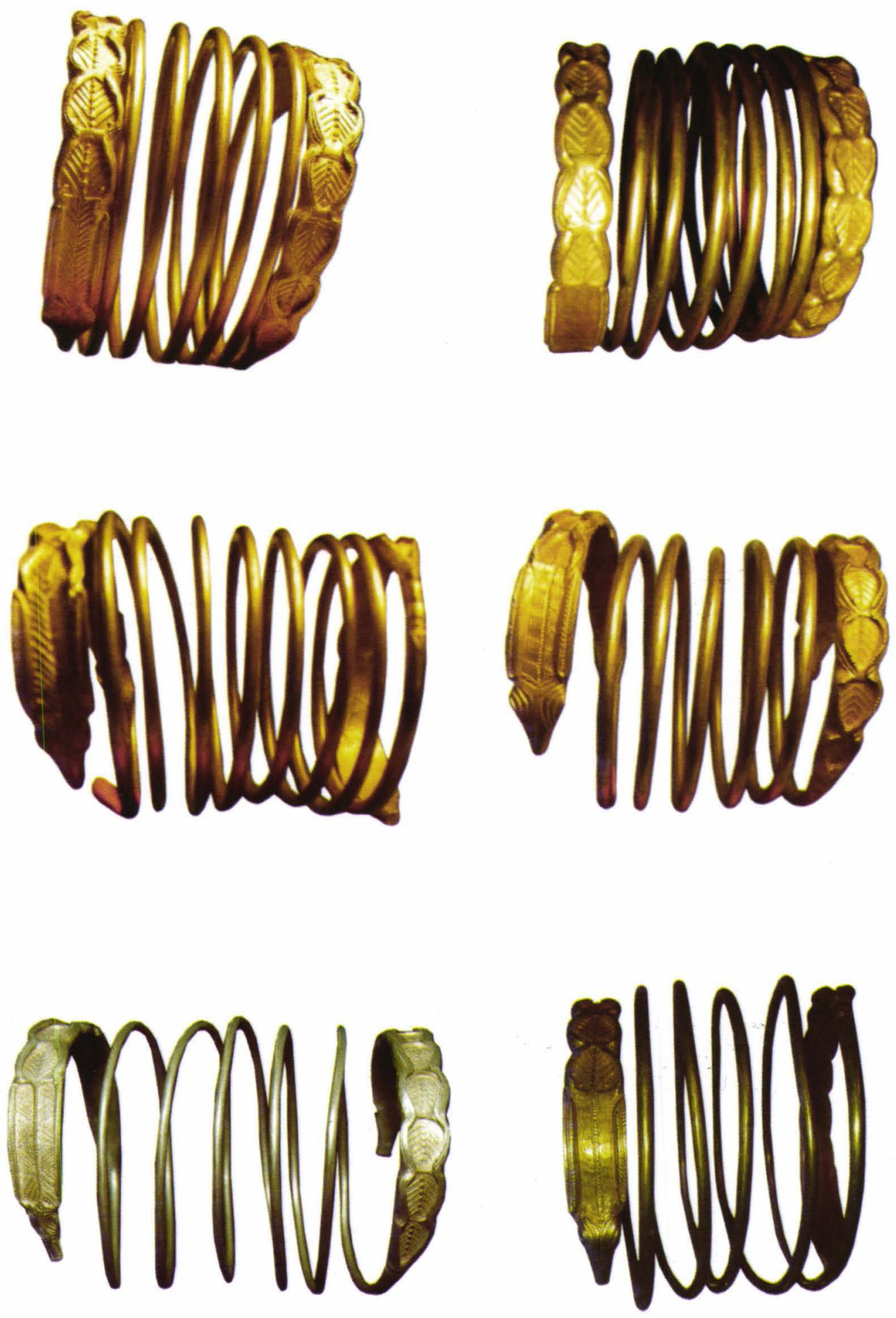

Pl. 1 - Brățările nr. 1-6. 

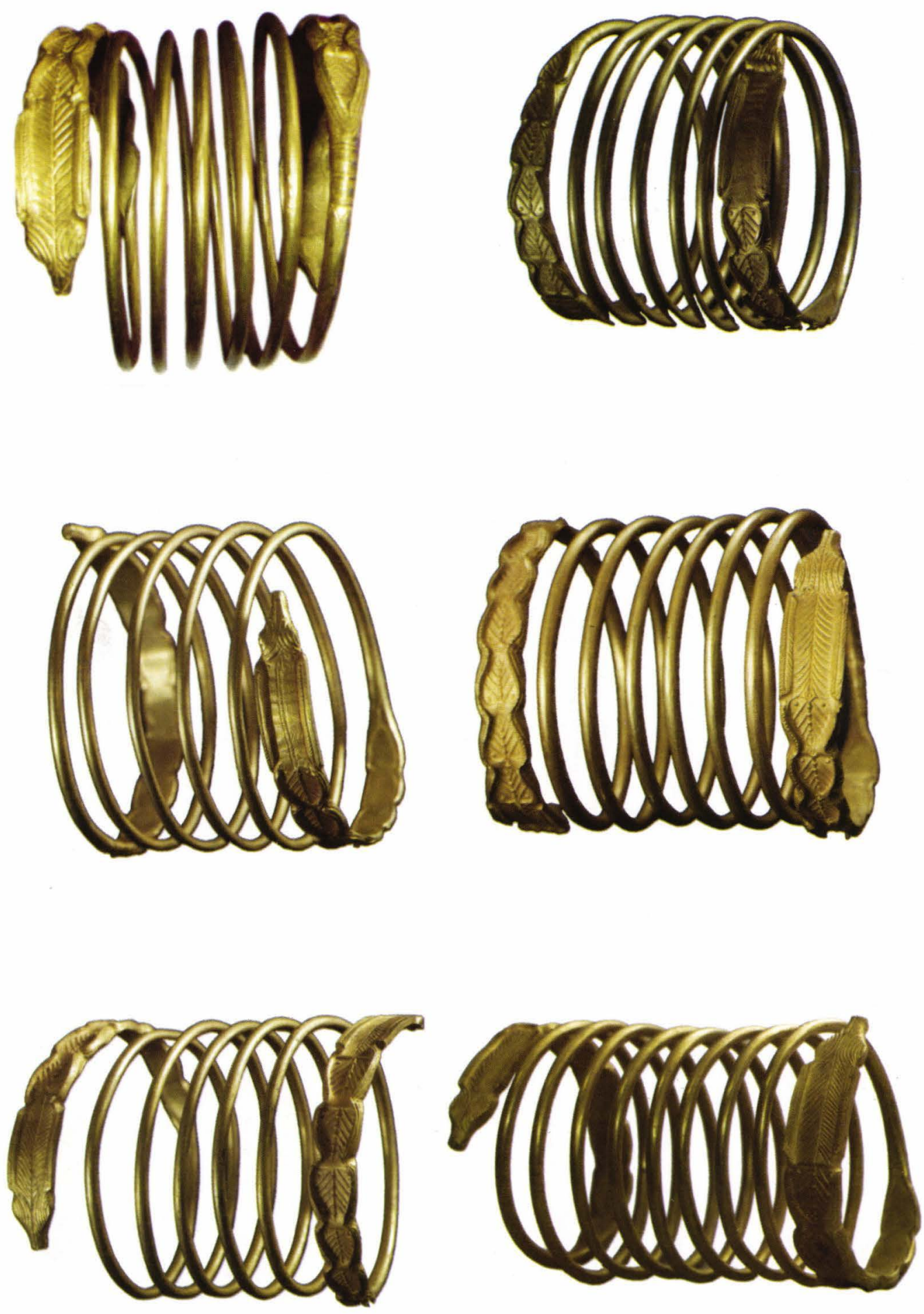

PI. 2 - Brățările nr. 7-12. 

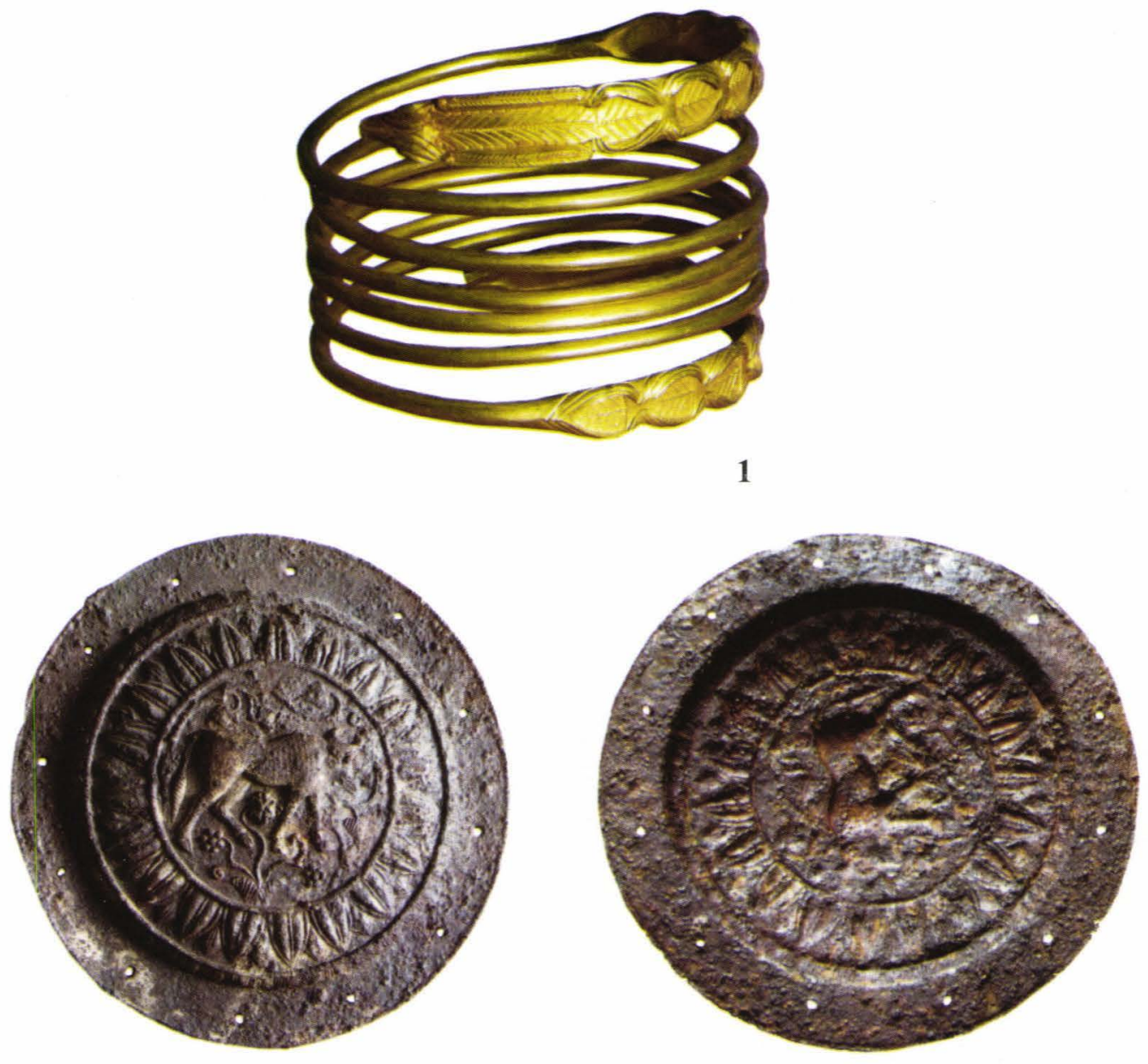

2
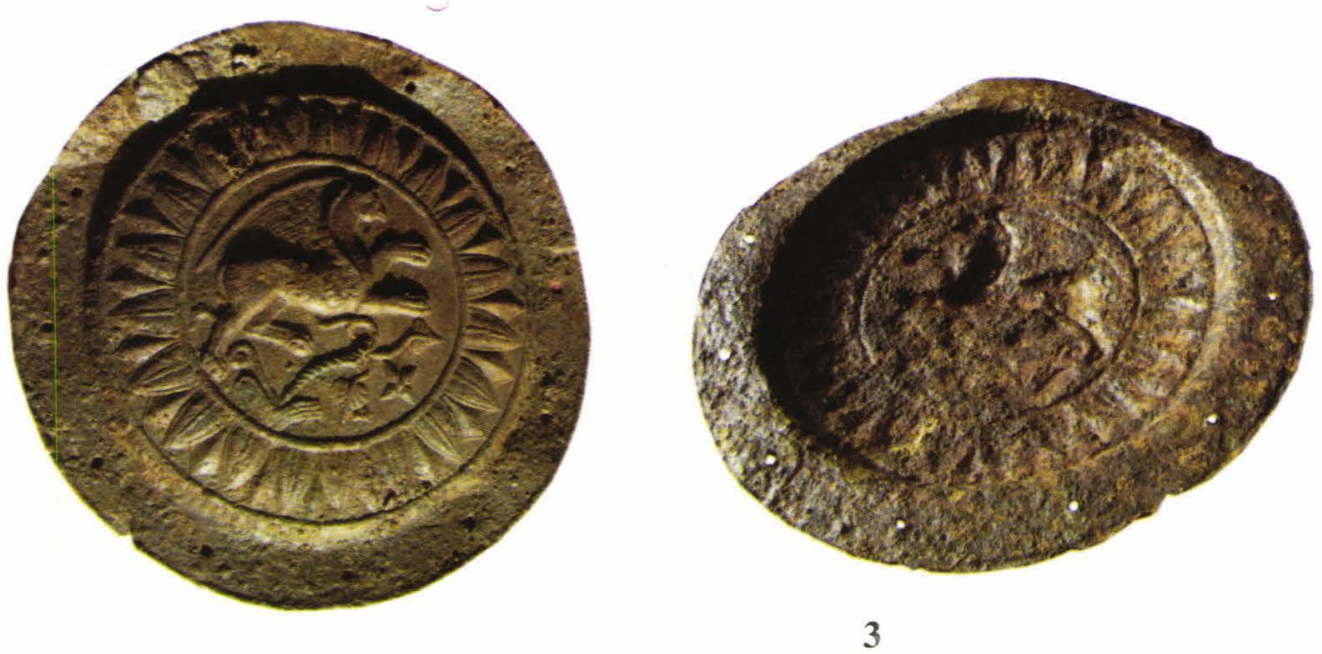

PI. 1 - 1. Brățara nr. 13; 2. Scutul nr. 1; 3. Scutul nr. 2 
